US Army Corps of Engineers ${ }_{\circledast}$

Engineer Research and

Development Center

OACSIM Environmental Quality Program Studies

\title{
Developing Baselines for Prescribed Burning Smoke Management Plans and Best Management Practices
}

Michael R. Kemme

September 2015
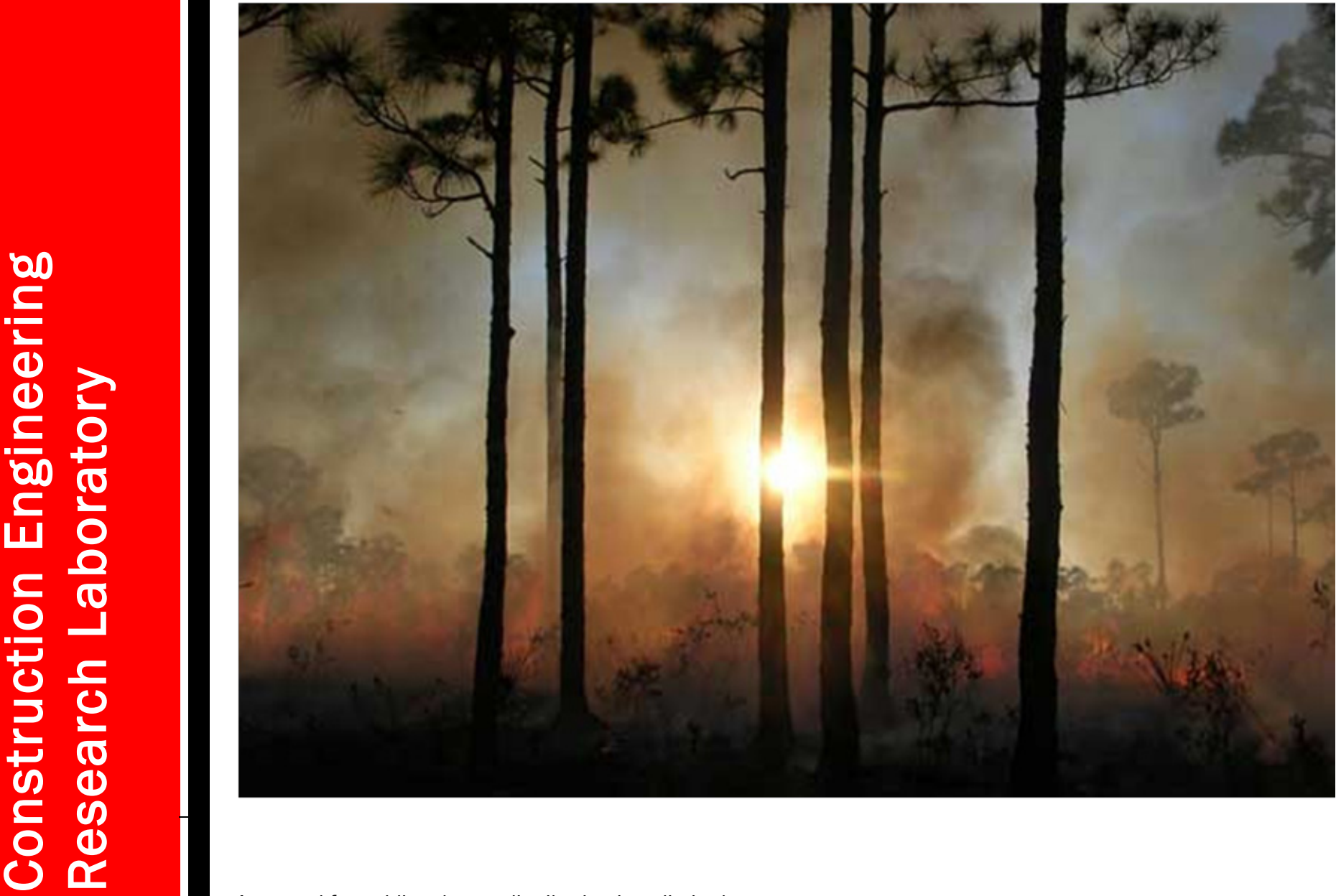
The U.S. Army Engineer Research and Development Center (ERDC) solves the nation's toughest engineering and environmental challenges. ERDC develops innovative solutions in civil and military engineering, geospatial sciences, water resources, and environmental sciences for the Army, the Department of Defense, civilian agencies, and our nation's public good. Find out more at www.erdc.usace.army.mil.

To search for other technical reports published by ERDC, visit the ERDC online library at http://acwc.sdp.sirsi.net/client/default. 


\section{Developing Baselines for Prescribed Burning Smoke Management Plans and Best Management Practices}

Michael R. Kemme

Construction Engineering Research Laboratory

U.S. Army Engineer Research and Development Center

2902 Newmark Drive

Champaign, IL 61822

Final report

Approved for public release; distribution is unlimited.

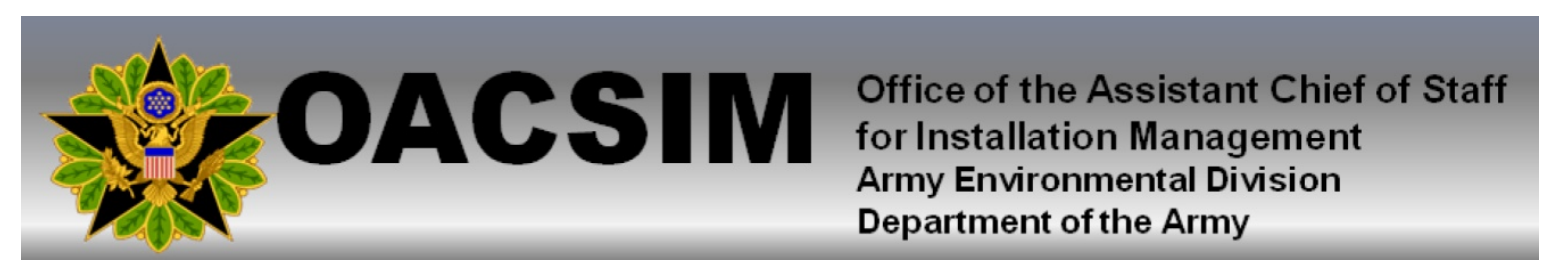

Prepared for Office of the Assistant Chief of Staff for Installation Management Army Environmental Division (ISE)

600 Army Pentagon

Washington, DC 20310-0600

Under Project 652BJ3, "Developing Baselines for Prescribed Burning Smoke Management Plan and Best Management Practices" 


\section{Abstract}

Prescribed fire is a critical component of Army wildland fire management and prevention, range maintenance, and ecosystem management. The U.S. Environmental Protection Agency (EPA) sets policy on controlling emissions from prescribed burning that is complex and still evolving. States have implemented EPA regulations and policy by developing their own regulations, Smoke Management Programs (SMPs), and State Implementation Plan conditions. A wide array of guidance for developing SMPs is available, along with tools for managing prescribed fire emissions. This information and many of these tools are applicable to Army installation management of prescribed burn smoke emissions. The Army already has the basic framework for developing SMPs within the installation-level Integrated Wildland Fire Management Plan that requires information on smoke management. However, this work discusses and recommends an approach for developing complete Army SMPs that align with the required elements of state/tribal SMPs. It is also recommended that a great deal of flexibility should be allowed in the installation-level SMP to account for variation in an installation's need to control smoke emissions and to meet state regulatory requirements.

DISCLAIMER: The contents of this report are not to be used for advertising, publication, or promotional purposes. Citation of trade names does not constitute an official endorsement or approval of the use of such commercial products. All product names and trademarks cited are the property of their respective owners. The findings of this report are not to be construed as an official Department of the Army position unless so designated by other authorized documents.

DESTROY THIS REPORT WHEN NO LONGER NEEDED. DO NOT RETURN IT TO THE ORIGINATOR. 


\section{Contents}

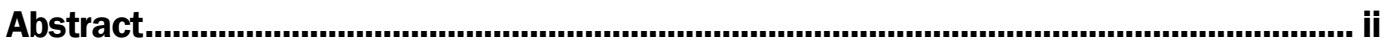

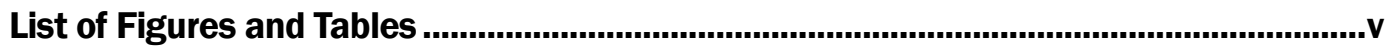

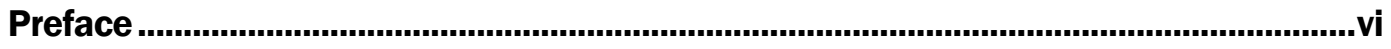

Unit Conversion Factors............................................................................................................

Abbreviations.........................................................................................................................vifi

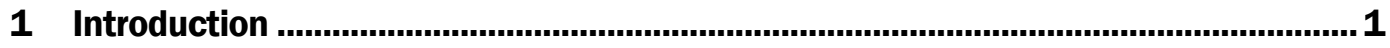

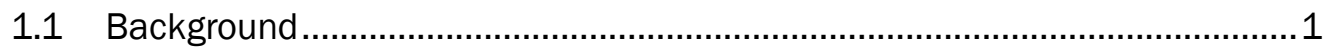

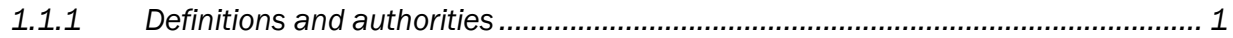

1.1.2 Army land's need for prescribed fire.............................................................. 1

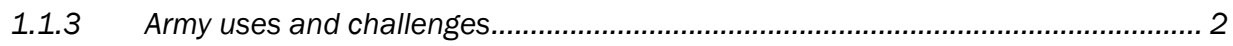

1.1.4 Using a smoke management plan ................................................................... 3

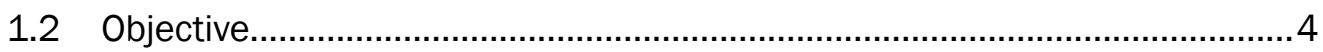

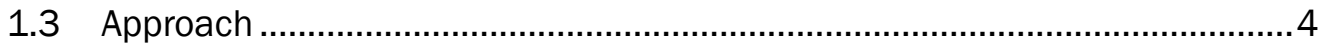

2 Regulatory Basis for Managing Smoke Emissions from Prescribed Fire and Development of Smoke Management Plans ....................................................5

2.1 National Ambient Air Quality Standards........................................................6

2.2 Interim Air Quality Policy on Wildland and Prescribed Fires ........................11

2.3 Exceptional Events Rule ........................................................................ 13

2.4 Regional Haze Regulations ......................................................................

3 Review of Smoke Management Resources or Guidance for Developing SMPs.

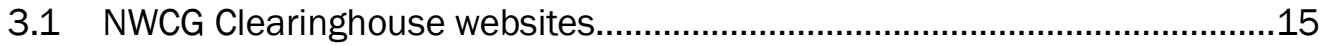

3.2 Interagency Prescribed Fire Planning and Implementation

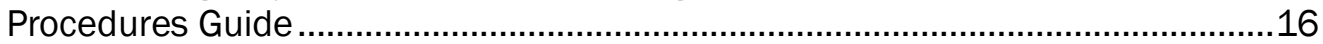

3.3 Smoke Management Guide for Prescribed and Wildland Fire .....................17

3.4 National Coalition of Prescribed Fire Councils Guide to Smoke

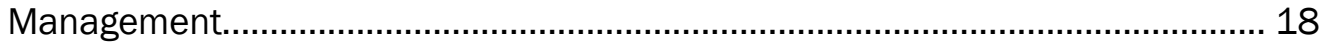

3.5 Basic Smoke Management Practices …...................................................19

3.6 Guidance for after-action review of smoke impacts................................. 20

4 Current Army Smoke Management Requirements .............................................21

5 Development of Army Installation Smoke Management Plans .............................23

5.1 Meteorology and smoke dispersion evaluation .......................................... 25

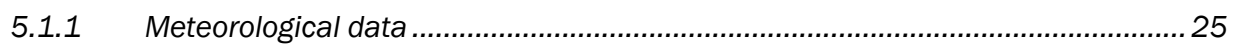

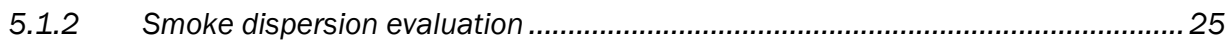




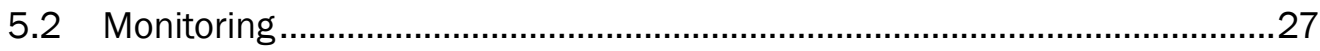

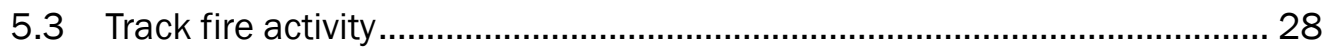

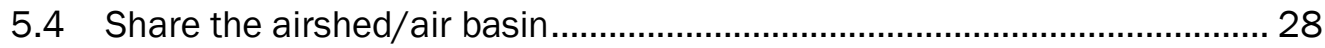

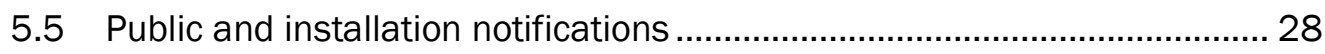

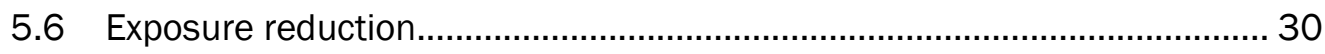

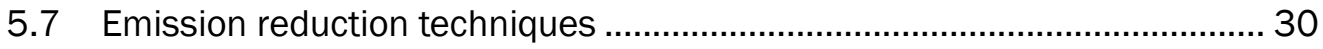

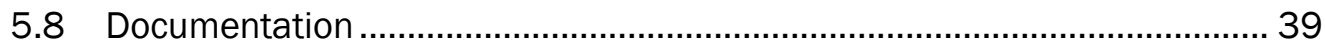

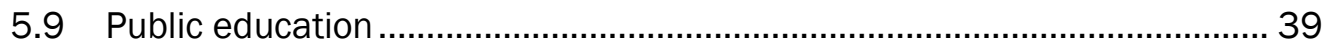

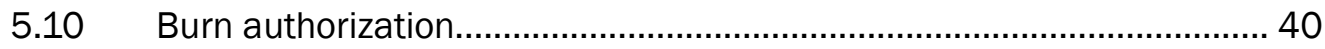

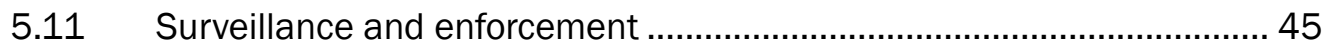

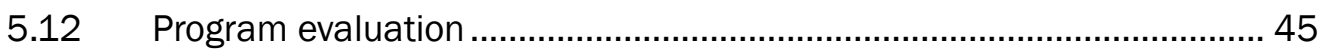

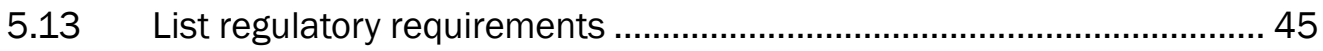

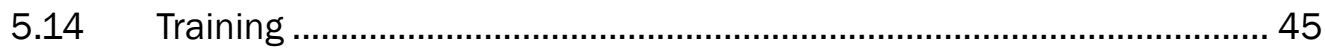

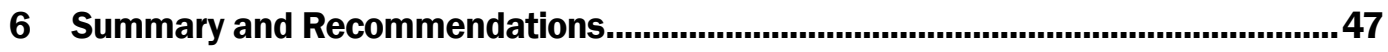

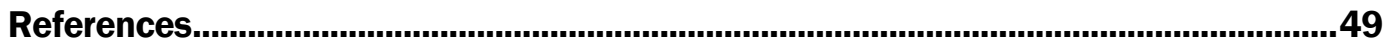

Appendix A: Interagency Prescribed Fire Plan Template (from NWCG 2014) ............51

\section{Report Documentation}




\section{List of Figures and Tables}

\section{Figures}

Figure 1. Annual $\mathrm{PM}_{2.5}$ emissions by source sector (from VISTAS project-Barnard and Sabos 2008, 207).

Figure 2. Army installations in $\mathrm{PM}_{2.5}$ nonattainment areas, July 2014 (ERDCCERL).

Figure 3. Army installations in ozone nonattainment areas, July 2014 (ERDCCERL).

Figure 4. Regional planning organizations formed by EPA's Regional Haze Program.

Figure 5. Example output from the Simple Smoke Screening Tool.* .

Figure 6. Agency Administrator Ignition Authorization, form PMS 485, used by agencies in the NWCG (NWGC 2014).

Figure 7. Prescribed fire go/no-go checklist, form PMS 486, used by agencies in the NWCG (NWGC 2014).

Figure 8. Prescribed fire pre-burn checklist used by Fort Gordon*

\section{Tables}

Table 1. Summary of Basic Smoke Management Practices (NRCS 2011). .......................19

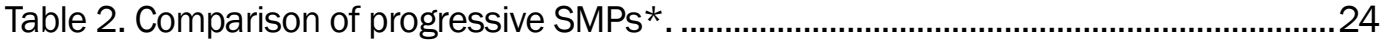

Table 3. Public notification form example (Fort Gordon, GA).............................................29

Table 4. Constraints and relative costs for smoke management practices (NWCG 2001).

Table 5. Approximate emission reduction effectiveness for emission reduction techniques used on specifc vegetation types (NWCG 2001). 


\section{Preface}

This study was conducted for the Office of the Assistant Chief of Staff for Installations Management, Installation Support Directorate, Environmental Division (OACSIM-ISE). The Deputy Director of ISE is Mr. Krishna Ganta, and the Director is COL Mary C. Williams-Lynch. The work was accomplished under Project 652BJ3, "Developing Baselines for Prescribed Burning Smoke Management Plan and Best Management Practices.” The Engineer Research and Development Center (ERDC) Program Manager was Mr. Alan Anderson. The OACSIM-ISE technical monitor was Mr. Robert W. Durham (DAIM-ISE).

The work was performed by the Environmental Processes Branch (CNE) of the Installations Division (CN), U.S. Army Engineer Research and Development Center - Construction Engineering Research Laboratory (ERDCCERL). At the time of publication, Mr. Garth Anderson was Acting Chief, CEERD-CNE; Ms. Michelle Hanson was Chief, CEERD-CN; and Mr. Alan B. Anderson was Technical Director for Sustainable Ranges and Lands. The Deputy Director of ERDC-CERL was Dr. Kirankumar Topudurti, and the Director was Dr. Ilker Adiguzel.

The Commander of ERDC was COL Bryan S. Green, and the Director was Dr. Jeffery P. Holland. 


\section{Unit Conversion Factors}

\begin{tabular}{|c|c|c|}
\hline Multiply & By & To Obtain \\
\hline acres & $4,046.873$ & square meters \\
\hline inches & 0.0254 & meters \\
\hline
\end{tabular}




\section{Abbreviations}

\begin{tabular}{|c|c|}
\hline Term & Definition \\
\hline & Miliy reguiacion \\
\hline BIA & Bureau of Indian Affairs \\
\hline BSMP & Basic Smoke Management Practice \\
\hline BMP & best management practice \\
\hline BLM & Bureau of Land Management \\
\hline CAA & Clean Air Act \\
\hline $\mathrm{CO}$ & carbon monoxide \\
\hline $\mathrm{CO}_{2}$ & carbon dioxide \\
\hline DES & Directorate of Emergency Services \\
\hline DoD & Department of Defense \\
\hline ESMP & enhanced smoke management program \\
\hline EPA & Environmental Protection Agency \\
\hline FMP & fire management plan \\
\hline GFC & Georgia Forestry Commission \\
\hline GHG & greenhouse gas \\
\hline ICRMP & Integrated Cultural Resources Management Plan \\
\hline INRMP & Integrated Natural Resources Management Plan \\
\hline IOC & Installation Operations Center \\
\hline IWFMP & Integrated Wildland Fire Management Plans \\
\hline KBDI & Keetch-Byram Drought Index \\
\hline NAAQS & National Ambient Air Quality Standards \\
\hline NEPA & National Environmental Policy Act \\
\hline NIFC & National Interagency Fire Center \\
\hline $\mathrm{NO}_{x}$ & nitrogen oxide \\
\hline NPS & National Park Service \\
\hline NWCG & National Wildfire Coordinating Group \\
\hline NRCS & Natural Resources Conservation Service \\
\hline NRMP & Natural Resources Management Plan \\
\hline OACSIM & Office of the Assistant Chief of Staff for Installation Management \\
\hline PAO & Public Affairs Office \\
\hline PM & particulate matter \\
\hline POC & point of contact \\
\hline RPOs & Regional Planning Organizations \\
\hline SIP & State Implementation Plan \\
\hline SMPs & Smoke Management Plans \\
\hline
\end{tabular}




$\begin{array}{ll}\text { Term } & \text { Definition } \\ \text { SmoC } & \text { Smoke Committee } \\ \text { SERDP } & \text { Strategic Environmental Research and Development Program } \\ \text { TES } & \text { Threatened and endangered species } \\ \text { USDA } & \text { U.S. Department of Agriculture } \\ \text { USFS } & \text { U.S. Forest Service } \\ \text { USFWS } & \text { U.S. Fish and Wildlife Service } \\ \text { VISTAS } & \text { Visibility Improvement State and Tribal Association of Southeast } \\ \text { VOC } & \text { volatile organic compound }\end{array}$


(This page intentionally left blank.) 


\section{Introduction}

\subsection{Background}

\subsubsection{Definitions and authorities}

The "Interagency Strategy for the Implementation of Federal Wildland Fire Management Policy" (National Wildfire Coordinating Group [NWCG] 2003) defines a wildland fire as any nonstructural fire that occurs in the wildland. It also defines wildfires and prescribed fire as the two types of wildland fire. A wildfire is defined as any unplanned ignition as well as planned ignitions that are declared wildfires. The wildfire term applies to all unplanned ignitions including events formerly termed wildland fire use. A prescribed fire is defined as any planned ignition and is sometimes also referred to as a controlled (or prescribed) burn.

Army Regulation (AR) 200-1 includes similar definitions and defines a wildland fire as "any non-structural fire that occurs on unimproved grounds. This includes wildfires and prescribed fires." AR 200-1 defines prescribed burning as "the skillful application of fire to natural fuels under conditions of weather, fuel moisture, soil moisture, etc., to allow confinement of the fire to a predetermined area while producing the intensity of heat and rate of spread required to accomplish certain planned benefits. These benefits may include all, or one or more, objectives such as silviculture, wildlife management, grazing, hazard reduction, etc. Its objective is to employ fire scientifically to realize maximum net benefits at minimum damage (if any) and acceptable cost.”

Army use of prescribed burning as part of an ecosystem-based land management strategy is also mandated in Department of Defense Instruction (DoDI) 4715.03 (DoD 2011).

\subsubsection{Army land's need for prescribed fire}

Prescribed fire is a critical component of Army wildland fire management/ prevention, range maintenance, and ecosystem management. Prescribed fire is employed by Army installations across the United States to reduce the frequency and intensity of wildfires by removing excess fuel loads. 
Range maintenance is enhanced by protecting training land assets from fire damage and developing lands suitable for training missions. In addition, fire-dependent ecosystems benefit from prescribed burn programs designed to mimic fire events previously provided by natural events.

Fire-dependent ecosystems are found across the southeastern and central United States, as well as portions of western United States; these ecosystems represent approximately 1,500,000 acres of Army training land and occur on $50 \%$ of all Tier 1 and Tier 2 Sustainable Range Program installations. Installations charged with sustainable management of firedependent ecosystems strive to implement prescribed burns at intervals that not only provide safe, accessible, maneuverable, and defensible range conditions necessary for mission training, but also support biodiversity and threatened and endangered species (TES) recovery. The Army reported 213 distinct TES on-site at 101 installations in FY10 (U.S. Army 2011). Many of these species are directly or indirectly dependent on reoccurring fire to control their habitats. The Army has a strategy of sustainability for applying a community, regional, and ecosystem approach to managing natural resources. This approach is described in The Army Strategy for the Environment (U.S. Army 2004). This strategy reinforces ecosystem-based fire management, which is a critical component of sustaining U.S. military missions.

\subsubsection{Army uses and challenges}

Challenges over Army use of prescribed fire for ecosystem management, forest health, fuel load reduction, and safety measures will require an increasing amount of coordination. Coordination of competing interests or mandates will be necessary to meet more stringent air quality standards while meeting regulatory requirements which may require prescribed burning for habitat requirements of endangered species or ecosystem management such as the Endangered Species Act. Because prescribed fire prevents potentially life-threatening wildfires and habitat destruction, it is imperative that prescribed burning be utilized as a tool. However, increased coordination is needed to ensure a balance is found between sometimes competing legal requirements.

Disagreements over Army use of prescribed fire will become increasingly pervasive due to public encroachment near military lands and the lower 
allowable levels in Environmental Protection Agency (EPA) air quality standards for fine particulate matter and ozone. The Clean Air Act and its amendments also impose restrictions on or alterations of Army prescribed burn programs, potentially creating a number of negative consequences for military training.

Failure to manage the Army's necessary prescribed burn programs could result in direct impacts to the training mission including restrictions on the time, frequency, and location of training-land use; loss of desirable training-land characteristics; increased risk of wildfires; and greater risks to the health and safety of troops and the public. Indirect impacts could include increased risk of wildfires spreading off-installation; reduced ability to meet Endangered Species Act compliance and recovery goals; increased costs due to loss of effective management strategies; and loss of prescribed fire as a highly effective tool for management of biodiversity, forest health, tick-borne diseases, and invasive species.

Thus, effective management of Army prescribed burning must strive to maximize prescribed fire's benefits while minimizing environmental impacts and consequences.

\subsubsection{Using a smoke management plan}

This report describes how a Smoke Management Plan (SMP) should be developed to document coordination with installation personnel and external state and local agencies. SMPs should be integrated with other installation planning such as the Wildland Fire Management Plan, Integrated Natural Resources Management Plan (INRMP), Integrated Cultural Resources Management Plan (ICRMP), Range Complex Master Plan (part of Integrated Training Area Management), and Real Property Master Plan. The SMP shall employ best management practices (BMPs) for burn practices and procedures, and it should document smoke management methods employed and information associated with prescribed burning activities. By following the SMP or BMPs, installation staff should be able to provide state and federal EPA staff with the needed information and justification required to continue prescribed burning on installations. A standardized SMP could be used as a stand-alone document or as a component of installation land management plans. 


\subsection{Objective}

This work was tasked with determining regulatory guidance and requirements for prescribed fire emissions, providing available smoke management resources that could be applied to Army prescribed burn smoke management programs, determining current Army requirements for prescribed burn smoke management, and developing recommendations for Army installation-level Smoke Management Plans (SMPs) and best management practices (BMPs).

\subsection{Approach}

The approach consisted of a review of EPA and state policies and requirements related to emissions from prescribed burns, a review of mostly online smoke management guidance and tools that might be useful to Army prescribed burn managers, a review of Army requirements for prescribed burn smoke management, and recommendations for Army installation-level SMPs and BMPs. 


\section{Regulatory Basis for Managing Smoke Emissions from Prescribed Fire and Development of Smoke Management Plans}

Wildland fires contain emissions of concern including greenhouse gasses (GHGs), photochemically reactive compounds (volatile organic compound [VOCs] and nitrogen oxides [NOx]), and particulate matter (PM). Emissions from prescribed fire are made up of a complex mixture of carbon dioxide $\left(\mathrm{CO}_{2}\right)$, water vapor, carbon monoxide $(\mathrm{CO})$, coarse and fine $\mathrm{PM}$, hydrocarbons and other organic chemicals, NOx, and trace minerals. Smoke composition depends on multiple factors including: fuel type and moisture content, fire temperature, wind conditions, other weatherrelated influences, and whether the smoke is fresh or "aged." Different fuel types can produce different compounds when burned because they are composed of varying amounts of cellulose, lignin, tannins and other polyphenols, oils, fats, resins, waxes, and starches.

The Strategic Environmental Research and Development Program (SERDP) funded two projects related to characterizing air emissions from Department of Defense (DoD) prescribed fire." The project, New Tools for Estimating and Managing Local/Regional Air Quality Impacts of Prescribed Burns (RC-1648) concentrated on DoD installations in the West and Southwest (Miller 2013), while the project Advanced Chemical Measurements of Smoke from DoD-Prescribed Burns (RC-1649) concentrated on DoD installations in the Southeast (Pacific Northwest National Laboratory 2013). Both projects included detailed emission data and emission factors for a wide variety of plant types and chemical species in plumes.

\footnotetext{
* Detailed information on both projects including links to their final reports can be found on the SERDP website at: https://www.serdp-estcp.org/Featured-Initiatives/Conservation/Fire/(list)/1/.
} 
PM is one of the principal pollutants of concern from prescribed fire. PM is either emitted directly or formed as the smoke plume interacts with the atmosphere while it travels downwind. PM is typically a mixture of both solid particles and liquid droplets. The size of particles affects their potential to cause health issues. Smaller particles, less than 2.5 micrometers $\left(\mathrm{PM}_{2.5}\right)$, can be inhaled into the deepest recesses of the lungs and have been linked with a variety of immediate health problems such as burning eyes, runny nose, illnesses such as bronchitis, and chronic health issues such as heart and lung diseases. Larger particles can irritate the eyes, nose, and throat.

Particles from prescribed fire smoke tend to be very small. The size distribution of PM can vary dramatically depending on conditions but in almost all cases, the majority of the emissions will be less than $\mathrm{PM}_{2.5}$. The physical and chemical processes generating secondary PM create very small particles that will be in the $\mathrm{PM}_{2.5}$ range. This particle size distribution is also near the wavelength of visible light (0.4-0.7 micrometers) and therefore smoke particles are very efficient at scattering light and reducing visibility. The visibility reducing properties of smoke can create extreme safety hazards when concentrated smoke plumes drift onto highways. Visibility reducing plumes from prescribed fires also leads to complaints.

Requirements that limit the amount or effects of prescribed fire emissions are established to prevent exceeding National Ambient Air Quality Standards (NAAQS) or to comply with regulations stemming from the Clean Air Act Amendments of 1990 (CAA). The NAAQS standards that most directly impact prescribed fire emissions are $\mathrm{PM}_{2.5}$ and ozone. Regulations that influence the management of prescribed fire emissions include the NAAQS, the Regional Haze Rule, and the Exceptional Events Rule. In April 1998, EPA issued an "interim" air quality policy on wildland and prescribed fires (USEPA 1998), available at: http://www.epa.gov/ttn/oarpg/t1/memoranda/firefnl.pdf).

\subsection{National Ambient Air Quality Standards}

On 21 September 2006, the U.S. EPA issued a suite of NAAQS for particle pollution. EPA strengthened the 24-hour primary $\mathrm{PM}_{2.5}$ standard (fine PM $\leq 2.5 \mu \mathrm{m}$ aerodynamic diameter) from the 1997 level of $65 \mu \mathrm{g} / \mathrm{m}^{3}$ to 35 $\mu \mathrm{g} / \mathrm{m}^{3}$, and retained the annual fine particle standard at $15 \mu \mathrm{g} / \mathrm{m}^{3}$ (49 CFR 50, 2006). On 14 December 2012, the U.S. EPA strengthened the annual 
health NAAQS for fine particles $\left(\mathrm{PM}_{2.5}\right)$ from $15 \mu \mathrm{g} / \mathrm{m}^{3}$ to $12.0 \mu \mathrm{g} / \mathrm{m}^{3}$ and retained the 24-hour fine particle standard of $35 \mu \mathrm{g} / \mathrm{m}^{3}$ (49 CFR 50, 2012). The agency also retained the existing standards for coarse particle pollution $\left(\mathrm{PM}_{10}\right)$.

Since the majority of PM emissions from prescribed fires are fine particles $\left(\mathrm{PM}_{2.5}\right)$, prescribed fire has been a source category under the scrutiny of regulators when $\mathrm{PM}_{2.5} \mathrm{NAAQS}$ is exceeded. In some states, prescribed burning emissions are a large contributor to the overall $\mathrm{PM}_{2.5}$ emission inventory. This can be seen in Figure 1 that shows relative contributions from all source categories to $\mathrm{PM}_{2.5}$ in ten southeastern states. Alabama, Georgia, Florida, and South Carolina are all states with significant contribution from fires category that includes prescribed burns. Although the benefits of prescribed fire are well understood, ways to limit these emissions will continue to be explored by regulators. This pressure increases when areas are designated nonattainment for $\mathrm{PM}_{2.5}$. Figure 2 is a map showing Army installations in $\mathrm{PM}_{2.5}$ nonattainment areas in July 2014.

Figure 1. Annual $\mathrm{PM}_{2.5}$ emissions by source sector (from VISTAS project-Barnard and Sabos 2008, 207).

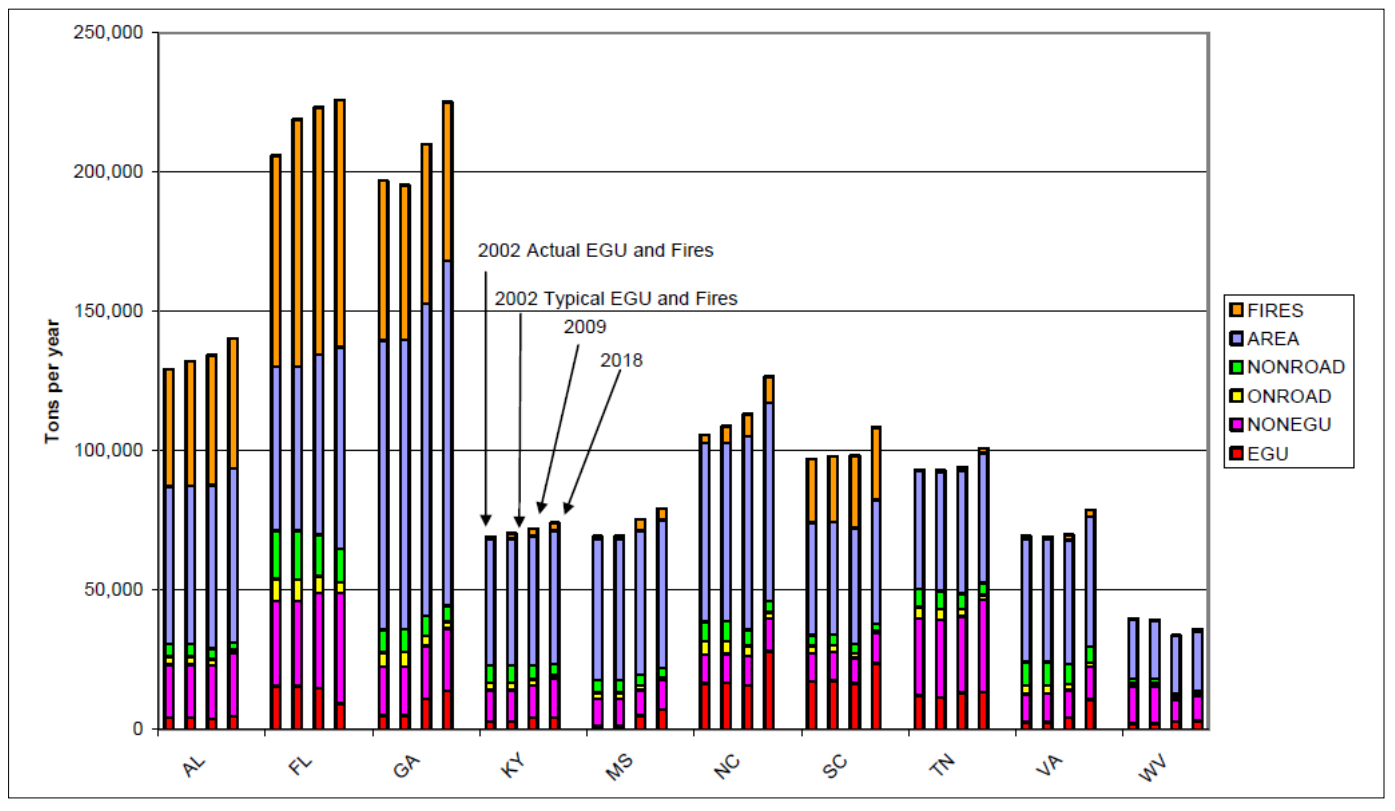

On 12 March 2008, the EPA limited the allowable amount of pollutionforming ozone in the air from 84 to 75 parts per billion (40 CFR 50 and $58,2008)$. Although the ozone NAAQS doesn't have as direct a connection to prescribed fire as the $\mathrm{PM}_{2.5}$ NAAQS, emissions of VOCs and NOx from 
prescribed fire have been implicated in ozone violations in nonattainment areas, sometimes several hundreds of miles downwind. Many parts of the country restrict prescribed fire use during the summer months as part of regional strategies to limit ozone formation. Figure 3 is a map showing Army installations in ozone nonattainment areas in July 2014. 
Figure 2. Army installations in PM2.5 nonattainment areas, July 2014 (ERDC-CERL).

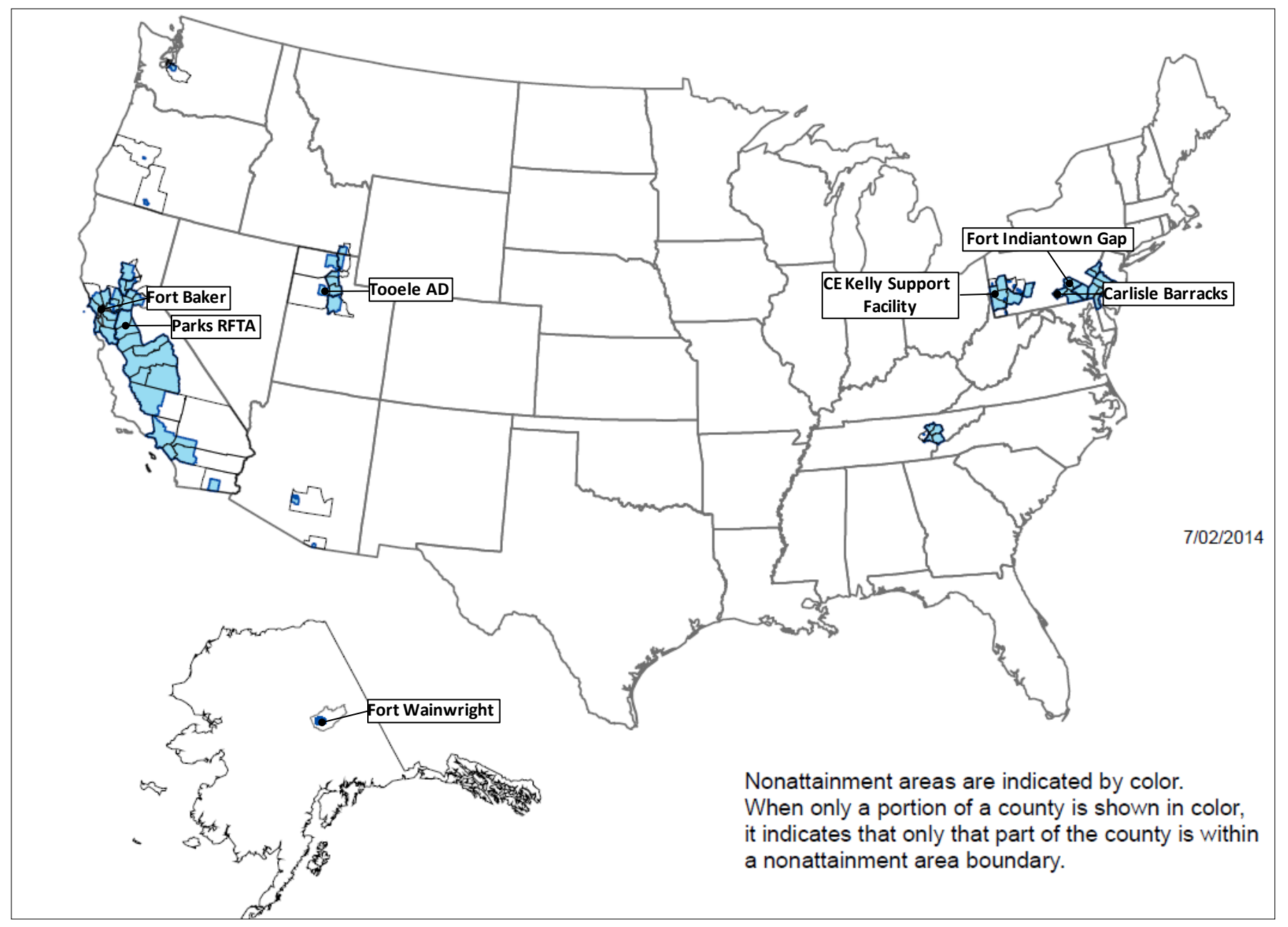


Figure 3. Army installations in ozone nonattainment areas, July 2014 (ERDC-CERL).

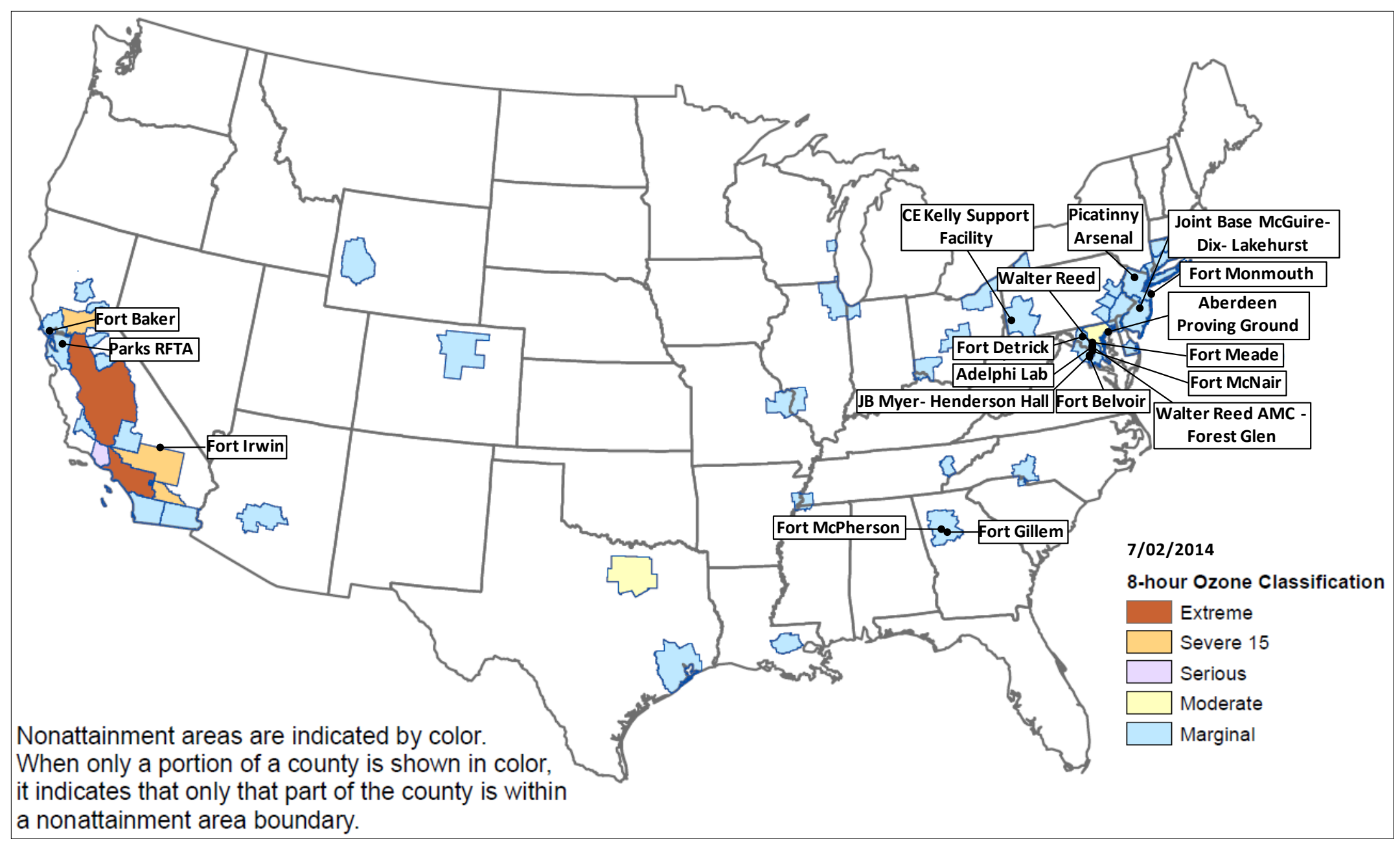




\subsection{Interim Air Quality Policy on Wildland and Prescribed Fires}

As mentioned in this chapter's introduction, the Interim Air Quality Policy on Wildland and Prescribed Fires is the most direct statement on prescribed fire from EPA (U.S. EPA 1998). This interim policy was developed to strike a balance between the need to protect the public health from wildland fire emissions and the many benefits provided by the use of wildland fire. The interim policy revolves around Smoke Management Programs developed by states/tribes. The interim policy states that:

The EPA does not directly regulate the use of fire within a state or on Indian lands. The EPA's authority is to enforce the requirements of the $\mathrm{CAA}$. The CAA requires states and tribes to attain and maintain the NAAQS adopted to protect public health and welfare. This policy recommends that states/tribes implement SMP's to mitigate the public health and welfare impacts of fires managed for resource benefits.

The interim policy provides incentives for state/tribes to certify their SMPs with the EPA. The incentives include the ability to allow voluntary participation by burners in the SMP, as long as fires do not cause or significantly contribute to daily or annual $\mathrm{PM}_{2.5}$ and $\mathrm{PM}_{10}$ NAAQS violations, and the SMP does not have to be adopted into the State Implementation Plan (SIP). Another incentive is the commitment by the EPA to use its discretion not to redesignate an area as nonattainment when fires cause or significantly contribute to NAAQS PM violations if the state/tribe required those fires to be conducted within a basic SMP.

The interim policy outlines what the content of state/tribe SMPs must be in order for the SMP to be certified by the EPA. The components include:

1. Authorization to burn

2. Minimizing air pollutant emissions

3. Smoke management components of burn plans

a. Actions to minimize fire emissions

b. Evaluate smoke dispersion

c. Public notification and exposure reduction procedures

d. Air quality monitoring

4. Public education and awareness

5. Surveillance and enforcement 
6. Program evaluation

7. Optional air quality protection

For federal land managers, including the DoD, the interim policy describes the development and use of long-term (10-15 yr) land use management plans and shorter-term ( $1-5 \mathrm{yr}$ ) fire management plans (FMPs). The planning results in documented management plans including FMPs. Federal agencies evaluate the environmental impacts of the tools used for resource management on publicly owned lands using the National Environmental Policy Act (NEPA).

The interim policy states that air quality and visibility impact evaluations of fire activities on federal lands should:

- Include recent historic (e.g., $10 \mathrm{yr}$ ) and projected (life of the plan) annual or seasonal emissions from wildland and prescribed fires. Emission projections should be based on estimates provided by wildland owners/managers of acres burned, pre-burn fuel loading by vegetation type and consumption.

- Be related to analyses of cumulative impacts of fires on regional and subregional air quality, when possible.

- Identify applicable regulations, plans or policies (e.g., burn plans, authorization to burn, conformity).

- Identify sensitive receptors.

- Include description of planned measures to reduce smoke impacts.

- Identify the potential for smoke intrusions into sensitive areas and model air quality and visibility impacts, when possible.

- Describe ambient air monitoring plans, when appropriate.

The EPA's interim policy is based on states and tribes developing somewhat standardized SMPs. The framework of state/tribal SMPs described in the interim policy may be a reasonable starting point for developing a similar framework for Army installation SMPs. There has been occasional activity towards updating EPA's policy, so some of the details described above could change. 


\subsection{Exceptional Events Rule}

On 22 March 2007, the EPA published a rule to establish criteria and procedures for determining if air-quality monitoring data have been influenced by exceptional events (U.S. EPA 2007). Basically, the Exceptional Events Rule provides that if an event causes violations of the NAAQS, EPA could use its discretion not to redesignate an area as nonattainment. For example, if a wildfire or a volcano caused a violation of the health standards, it would not make sense to designate the affected area as nonattainment for a source that could not be controlled.

This rule has the potential to provide state regulatory agencies some relief when prescribed burn events cause a NAAQS to be exceeded. The rule states that wildfires or "wildland fire use fires" will be treated as natural events. Prescribed fires managed for resource benefits may qualify for exceptional events if they meet certain criteria:

- if they are unlikely to reoccur at the same location and are not reasonably controllable or preventable, and

- if the state certifies that an SMP or basic smoke management practices (BSMP), was in place.

When prescribed fires are applied at the natural return interval for an ecosystem and the prescribed fire is preventing more catastrophic wildfires, it may be possible to meet these criteria. These decisions will be made on a case-by-case basis. If a particular burn on an Army installation is suspected of causing an excursion of an NAAQS, state regulators may contact the installation to gather information to determine if the prescribed fire can qualify as an exceptional event. In 2013, the EPA finalized a rule to establish criteria and procedures for use in determining if air quality monitoring data has been influenced by exceptional events.*

EPA's handling of data from all other fires will continue to be addressed under its "Interim Air Quality Policy on Wildland and Prescribed Fires."

\footnotetext{
* For more information, refer to the EPA's Technical Transfer Network website on Exception Events at http://www.epa.gov/ttn/analysis/exevents.htm which offers a link to its factsheet on the subject at: http://www.epa.gov/ttn/analysis/docs/exceptevents fs 130510.pdf.
} 


\subsection{Regional Haze Regulations}

EPA and state visibility regulations were developed to help meet the national visibility goal identified in Section 169A of the CAA which is "the prevention of any future, and the remedying of any existing impairment of visibility in mandatory Federal Class I areas from man-made air pollution.” EPA finalized their Regional Haze Regulations on July 1, 1999 (U.S. EPA 1999). These regulations specifically addressed fire for many states in the West (see Section 51.309 of the Regional Haze Regulations) and generally addressed fire in the rest of the states.

All states with Class I areas are required to amend their SIPs to identify how they will prevent future visibility impairment and remedy existing impairment of visibility. As a part of their visibility regulations, EPA requires that states, in their SIPs, consider the impacts of prescribed burning on visibility and the adequacy of their SMPs. Five Regional Planning Organizations (RPOs) have been established to help states develop programs to implement the Regional Haze Regulations. These RPOs are shown in Figure 4 .

Figure 4. Regional planning organizations formed by EPA's Regional Haze Program.

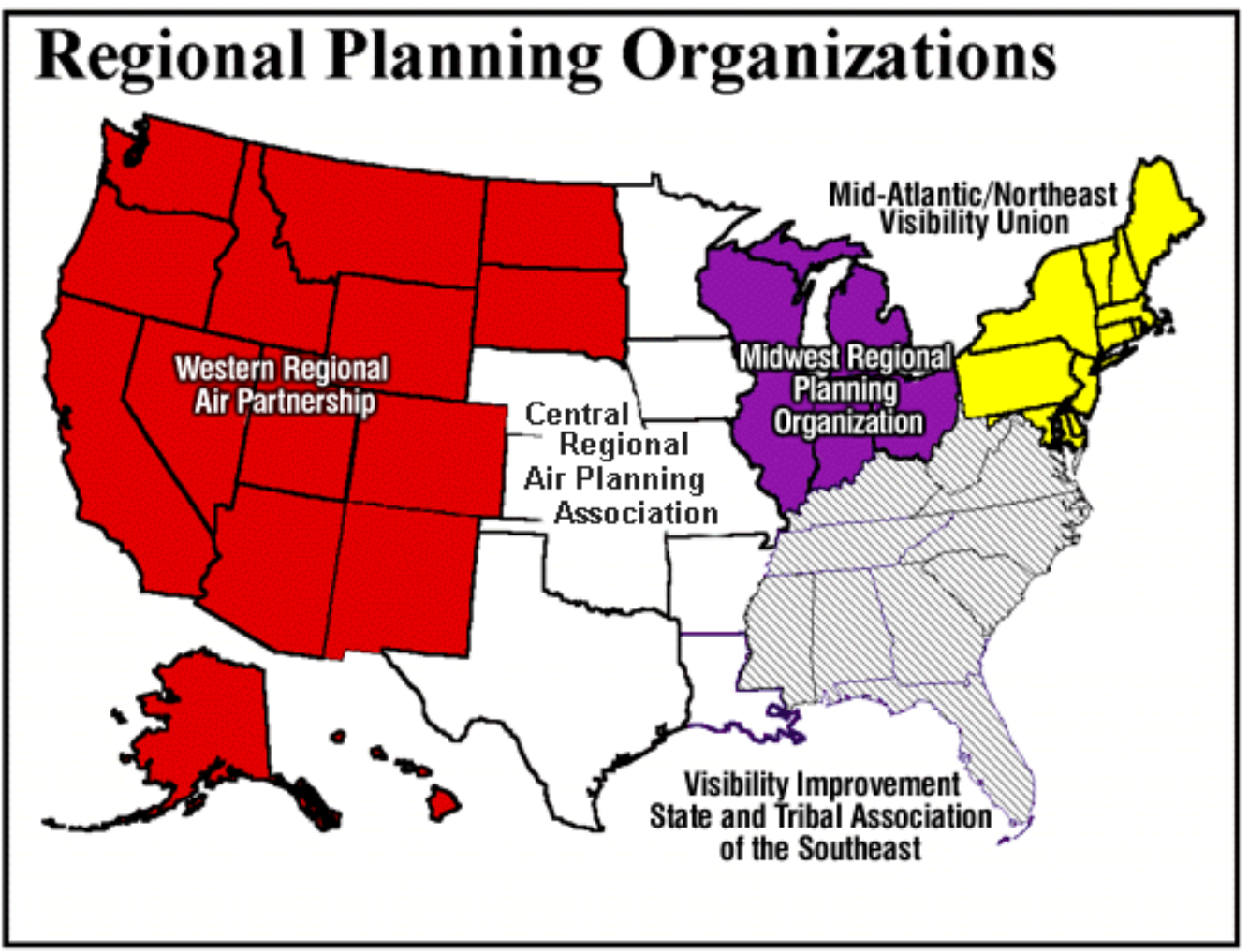




\section{Review of Smoke Management Resources or Guidance for Developing SMPs}

To help shape the components and implementation of Army installation SMPs, smoke management guidance and smoke management resources were reviewed. Descriptions of the available guidance and resources that appeared to be most applicable to the Army's management of prescribed burn emissions are provided below.

\subsection{NWCG Clearinghouse websites}

The NWCG Smoke Committee (SmoC) has developed several websites and information resources related to managing smoke emission from wildland fires. The SmoC has an "Air Quality and Fire Issues" community website for presenting updates to SmoC activities and as a place to share information about air quality as it relates to fire. A link to this site can be found on the "My Fire Communities" website (http://wildfirelessons.net/communities/neighborhoods). This site has a great deal of information including links to other related sites or documents.

The NWCG SmoC has also developed the Emissions and Smoke Portal (http://www.frames.gov/partner-sites/emissions-and-smoke/smoke-portal-home/). This site is divided into sections such as educational resources, smoke research, documents library, and smoke management resources. The educational resources section contains an online smoke management course, a glossary of smoke management terms, case studies, recorded presentations on effective communications for smoke management, and links to air quality documents and tools.

The National Interagency Fire Center (NIFC) is the nation's support center for wildland firefighting. One of the NIFC's fire program areas is smoke management. The NIFC hosts a smoke management website that is a very comprehensive clearinghouse for smoke management information (http://www.nifc.gov/smoke/). This webpage was developed by the NWCG SmoC. The webpage is divided into smoke management tools, regulations and policies, emissions, training, publications, and other links. 


\subsection{Interagency Prescribed Fire Planning and Implementation Procedures Guide}

The Interagency Prescribed Fire Planning and Implementation Procedures Guide was developed by NWCG and provides standardized procedures for planning and implementing prescribed fire (NWCG 2014). The agencies that agreed to these standardized approaches include the Department of the Interior's Bureau of Indian Affairs (BIA), Bureau of Land Management (BLM), the National Park Service (NPS), the U.S. Fish and Wildlife Service (USFWS), and the U.S. Department of Agriculture Forest Service (USFS).

The information in the guide may be useful to Army installations. The guidance describes 21 elements of a prescribed fire plan and provides a template for these plans. These elements are similar to the elements required to be contained in an Army Integrated Wildland Fire Management Plan (IWFMP) that are described in Section 4 of this report. The guide covers all aspects of prescribed fire management with only Element 19 of the plan being directly focused on smoke management. Other sections of the guide contain aspects of smoke management via descriptions of prescribed fire personnel's smoke management responsibilities, inclusion of smoke exposure in the safety discussion, and descriptions of the relationships of smoke management to other elements of the prescribed fire plan. The Interagency Prescribed Fire Plan Template from this guide can be found in Appendix A.

Element 19 of the guide, dedicated to smoke management and air quality, must include:

- compliance with local, county, state, tribal, and federal air quality regulations;

- identification of smoke sensitive receptors; and

- inclusion of any modeling outputs and any mitigation strategies and techniques.

The section mentions specific air quality compliance issues including being located in a nonattainment area for a NAAQS, the potential for prescribed fire to impact Class I areas, the potential for notices of violation, and information needs for prescribed burns to be qualified as exceptional events. Two reference documents are mentioned: the "Smoke Manage- 
ment Guide for Prescribed and Wildland Fire," which is discussed in Section 3.3, and the "Guidance for After Action Review of Smoke Impacts," which is discussed in Section 3.6.

\subsection{Smoke Management Guide for Prescribed and Wildland Fire}

This guide was developed by NWCG and provides discussions of topics related to managing smoke emissions from wildland fires (NWCG 2001). There are a large number of chapters devoted to background information, followed by chapters on specific topics of interest to managing smoke emissions. This document is quite often cited in wildland management plans as the primary source of emission reduction measures. As previously noted, there are plans to update this guide, but it isn't clear when this will occur. All of the information presented in the guide is useful as long as readers are careful about understanding the types of information that may have changed since 2001. Information presented in the guide regarding air quality regulations, air dispersion modeling systems, and air monitoring technology would especially benefit from an update. Sections in the guide that are still relevant to Army prescribed burn smoke management include chapters on fire use planning, smoke management meteorology, and smoke management techniques to reduce or redistribute emissions.

The guide's smoke management techniques include two general approaches to managing the effects of wildland fire smoke: techniques that reduce emissions from a given area and techniques that redistribute the emissions through meteorological scheduling and by sharing the airshed. Emission reduction techniques discussed include:

- reducing the area burned by concentrating burns, isolating fuels, or mosaic burning;

- reducing the fuel load through mechanical removal, mechanical processing, firewood sales, collection of biomass for electrical generation, collection of biomass for other uses (e.g., pulp for paper, garden bedding, and wood pellets), or use of ungulates for grazing;

- reducing fuel production through chemical treatments, site vegetation composition conversion, or land use changes;

- reducing fuel consumed through high moisture in large woody fuels, moist litter or duff, burning before precipitation, or burning before large fuels cure; 
- scheduling burning before new fuels appear by burning before litter fall or burning before green-up; and

- increasing combustion efficiency through use of burn piles or windrows, backing fires, burning under dry conditions, rapid mop-up, aerial ignition/mass ignition, or use of air curtain incinerators.

Emission redistribution techniques include burning when the dispersion characteristics of the atmosphere are good, being aware of other burn events in the same airshed, avoiding smoke intrusion on sensitive areas, burning smaller units, and burning more frequently.

The applicability and effectiveness of these techniques will vary widely depending on the specific conditions found on installations and the objectives of the prescribed burns. Therefore local experience at installations will play a very large role in deciding how to apply these techniques.

\subsection{National Coalition of Prescribed Fire Councils Guide to Smoke Management}

This guide was developed as a reference for Prescribed Fire Councils and their members when trying to develop smoke management programs at a local level that best meet local fire management and air quality needs (National Coalition of Prescribed Fire Councils 2007). Many states have Prescribed Fire Councils, and Army installation personnel participate in these organizations. This guide does a good job of summarizing the many issues related to prescribed fire smoke management. It describes:

- The role of fire in managing ecosystems

- Changes in national fire management policy

- The impact of fire on air quality

- EPA's role in development of air pollution regulations (what congress requires them to do)

- Existing federal air pollution standards and regulations (what we need to deal with now)

- Potential federal air pollution standards and regulations (looking forward)

- States' roles in development of air pollution regulations (what EPA requires them to do) 
- How local air quality regulations and programs are developed (opportunities for involvement)

- How to become effectively involved in the development of air quality regulations at the state and local level (how to play to win)

- Options to minimize the amount and/or impact of smoke produced from prescribed fire

- What is appropriate in a state or local smoke management program

- How to influence public support for prescribed fire

- The role of prescribed fire councils in addressing air quality issues

\subsection{Basic Smoke Management Practices}

The "Basic Smoke Management Practices" technical note was developed by the U.S. Department of Agriculture, Natural Resources Conservation Service (NRCS 2011). It presents six BSMPs that can mitigate the impacts of smoke emissions from prescribed burns. Table 1 summarizes the BSMPs.

Table 1. Summary of Basic Smoke Management Practices (NRCS 2011).

\begin{tabular}{|l|l|l|}
\hline $\begin{array}{l}\text { Basic Smoke Management } \\
\text { Practice }\end{array}$ & Benefit Achieved with the BSMP & $\begin{array}{l}\text { When the BSMP is Applied - } \\
\text { Before/During/After the Burn }\end{array}$ \\
\hline $\begin{array}{l}\text { Evaluate Smoke } \\
\text { Dispersion Conditions }\end{array}$ & Minimize smoke impacts. & Before, during, after \\
\hline $\begin{array}{l}\text { Monitor Effects on Air } \\
\text { Quality }\end{array}$ & $\begin{array}{l}\text { Be aware of where the smoke is } \\
\text { going and the degree to which it } \\
\text { impacts air quality. }\end{array}$ & Before, during, after \\
\hline $\begin{array}{l}\text { Record-Keeping/Maintain } \\
\text { a Burn/Smoke Journal }\end{array}$ & $\begin{array}{l}\text { Retain information about the } \\
\text { weather, burn, and smoke. If air } \\
\text { quality problems occur, } \\
\text { documentation helps analyze and } \\
\text { address air regulatory issues. }\end{array}$ & Before, during, after \\
\hline $\begin{array}{l}\text { Communication - Public } \\
\text { Notification }\end{array}$ & $\begin{array}{l}\text { Notify neighbors and those } \\
\text { potentially impacted by smoke, } \\
\text { especially sensitive receptors. }\end{array}$ & Before, during \\
\hline $\begin{array}{l}\text { Consider Emission } \\
\text { Reduction Techniques }\end{array}$ & $\begin{array}{l}\text { Reducing emissions can reduce } \\
\text { downwind impacts. }\end{array}$ & Before, during \\
\hline $\begin{array}{l}\text { Share the Airshed - } \\
\text { Coordination of Area } \\
\text { Burning }\end{array}$ & $\begin{array}{l}\text { Coordinate multiple burns in the area } \\
\text { to manage exposure of the public to } \\
\text { smoke. }\end{array}$ & Before, during, after \\
\hline
\end{tabular}


All of these BSMPs could be applied at Army installations. The basic nature of these smoke management practices also applies to the limited nature of many Army installations' use of prescribed fire.

\subsection{Guidance for after-action review of smoke impacts}

This guidance found on the NIFC website describes actions to be taken after a known smoke impact has occurred (NIFC 2008). It describes the type of information that should be collected during prescribed burns to allow a proper after-action review, and the steps a review should take so that lessons can be learned to prevent a similar event occurring in the future. The exact details presented in the guidance may not all be applicable to Army installations, but the intent and general steps presented are applicable. 


\section{Current Army Smoke Management Requirements}

The Army Wildland Fire Policy Guidance (U.S. Army 2002) requires that all "installations with unimproved grounds that present a wildfire hazard and/or installations that utilize prescribed burns as a land management tool" to develop and implement an IWFMP that is integrated with the installation's INRMP, existing fire and emergency service program plan(s), and ICRMP.

The guidance describes the purpose of the IWFMP is to:

- reduce wildfire potential,

- effectively protect and enhance valuable natural resources,

- integrate applicable state and local permit and reporting requirements, and

- implement ecosystem management goals and objectives on Army installations.

The guidance requires that the IWFMP be reviewed and updated annually and revised at least once every 5 years. The guidance outlines 15 components of IWFMPs and describes program authority for fire management. The guidance also includes certification, training, and fitness standards for wildland fire management personnel.

IWFMPs must incorporate a section on prescribed fires that includes sitespecific burn plans. The NWCG Prescribed Fire Plan found in Appendix A provides the template used by many federal agencies to develop sitespecific burn plans that contain all of the Army's required elements. At a minimum, Army guidance requires that burn plans include:

- burn objectives,

- acceptable weather and fuel moisture parameters,

- required personnel and equipment resources,

- burn area map,

- smoke management plan,

- safety considerations, 
- pre-burn authorization/notification checklist,

- coordination to consider wildlife, endangered species, cultural resources, and noxious weed effects,

- alternative plan of action if wind direction changes during prescribed burn, and

- a plan for analysis of burn success and identification of lessons learned.

The section on Smoke Management and Air Quality should describe mission, environmental, human health, and safety factors. The section also includes applicable state and local permit reporting requirements specific to the installation and region that affect smoke management and identify necessary mitigation practices. The fire policy guidance cites the NWCG publication, "Smoke Management Guide for Prescribed and Wildland Fire" that was described in Section 3.3, for guidance on factors to consider including in the section.

The IWFMP and its requirement for a "Smoke Management Plan" section provide a basic framework for the inclusion of SMP components. Many IWFMPs do include many SMP elements but not always in a coherent or consistent manner.

Suggested improvements to the current IWFMP, based on SMP components, follow in Chapter 5 . 


\section{Development of Army Installation Smoke Management Plans}

As discussed in Section 4, the Army already has the basic framework necessary to document SMP elements within the installation-level IWFMPs. The intent of this section is to recommend how various SMP components can be implemented and documented to provide a complete SMP for Army installations. The process for internal and regulatory coordination to implement SMP components should be well developed and documented. SMPs can help to minimize smoke entering populated areas, to prevent public safety hazards, to avoid significant contribution to NAAQS violations, to provide a process to collect data for nuisance mitigation or state regulatory request for Exceptional Event Rule demonstrations, and to avoid visibility impacts in Class I areas.

Some states/tribes have developed SMPs to manage emissions from wildland fires and wildfires. If there is a state/tribal SMP for an installation's location, then the installation should follow the requirements of the applicable SMP. The regulatory basis for states/tribes developing SMPs was discussed in Section 2. The basic components of these SMPs may provide a basis for Army installation-level SMPs. The plans are generally categorized into three progressive levels: BSMPs, SMPs, and enhanced smoke management programs (ESMPs). Table 2 shows a comparison of the elements that comprise the three types of plans. BSMPs were described in the Exceptional Event Rule (U.S. EPA 2007) for states/tribes where no formal SMP had been adopted. When smoke-related exceptional events occur, then the state/tribe must consider developing an SMP. The ESMP is described in the Regional Haze Rule (U.S. EPA 1999) and is to be developed by states/tribes when SMPs are not sufficient to protect visibility in Class I areas.

An Army installation SMP would likely fall into the category of a BSMP or SMP, although the concept of setting wildland fire emission goals may make sense for installations with major smoke impact issues. The level of detail and requirements for Army SMPs will depend on the impact that smoke-producing activities have on the sensitive areas and the requirements placed on the installation by state or local regulations and state- 
level SMPs. Army installation-level SMPs would also likely include information on training requirements, a listing of state smoke management regulations, and a description of the state's SMP.

Table 2. Comparison of progressive SMPs*.

\begin{tabular}{|l|c|c|c|}
\hline Elements & BSMP & SMP & ESMP \\
\hline $\begin{array}{l}\text { Meteorology and Smoke Dispersion } \\
\text { Evaluation }\end{array}$ & $\mathrm{C}$ & $\mathrm{C}$ & $\mathrm{R}$ \\
\hline Monitoring & $\mathrm{C}$ & $\mathrm{C}$ & $\mathrm{R}$ \\
\hline Track Fire Activity & $\mathrm{C}$ & $\mathrm{C}$ & $\mathrm{R}$ \\
\hline Share the Airshed/Air Basin & $\mathrm{O}$ & $\mathrm{O}$ & $\mathrm{R}$ \\
\hline Public Notification & $\mathrm{O}$ & $\mathrm{O}$ & $\mathrm{R}$ \\
\hline Exposure Reduction & $\mathrm{O}$ & $\mathrm{O}$ & $\mathrm{R}$ \\
\hline Emission Reduction Techniques & $\mathrm{O}$ & $\mathrm{O}$ & $\mathrm{R}$ \\
\hline Documentation (keep for 3.5 yrs) & $\mathrm{O}$ & $\mathrm{C}$ & $\mathrm{R}$ \\
\hline Public Education & - & $\mathrm{O}$ & $\mathrm{R}$ \\
\hline Burn Authorization & - & $\mathrm{O}$ & $\mathrm{R}$ \\
\hline Surveillance and Enforcement & - & $\mathrm{O}$ & $\mathrm{R}$ \\
\hline Program Evaluation & - & $\mathrm{O}$ & $\mathrm{R}$ \\
\hline Regional Coordination & - & - & $\mathrm{R}$ \\
\hline Annual Emissions Goals /Minimize Emissions & - & - & $\mathrm{R}$ \\
\hline
\end{tabular}

* C - Critical, O - Optional, R - Required

Army installation-level SMP components are now most often found in installation IWFMPs. Smoke management is not usually concentrated in one section but is integrated with procedures used for attaining prescribed burn objectives and maintaining safety. The required "Smoke Management Plan" section of the IWFMP is often a general statement about the need to manage smoke emissions and does not always refer to all the smoke management practices found elsewhere in the IWFMP. For most installations, a better alternative would be to include all aspects of smoke management in the "Smoke Management Plan" section, with references made to related practices found in the IWFMP as needed. The following sections will cover each of the BSMP and SMP components found in Table 2 and discuss how they might be implemented on installations and documented in the SMP portion of the IWFMP. 


\subsection{Meteorology and smoke dispersion evaluation}

Installations generating prescribed burn smoke emissions need to collect relevant forecasted meteorological information as part of a Go/No-Go decision process and as an input to an analysis of the potential for smoke emissions to impact smoke-sensitive areas. The impact analysis should be made based on the meteorological data itself and through a smoke dispersion evaluation. The Go/No-Go decision process is discussed below in Section 5.10 .

\subsubsection{Meteorological data}

Required meteorological information may include: wind speed (near the surface and aloft), wind direction, humidity, mixing height, ventilation index, atmospheric stability, and the vertical temperature profile of the atmosphere and inversions. A particular source and format of this information may be required by state programs. If the exact data source is not specified, there are many online outlets for this information. The NIFC website discussed in Section 3.1 contains links to several fire weather sites. If feasible, it is a good idea to supplement forecasted information with weather data collected during the burn by using either automated weather stations found on the installations or observations made near the burns. Weather data collected after the burn may also become important if there are still significant smoldering fuels.

In the SMP portion of the IWFMP, the source and type of meteorological data should be documented. The method of recording forecasted and observed meteorological data should also be documented. It is always a good idea to include examples of forms and data in the appendices of the IWFMP. All collected meteorological data must be saved to document the condition and for potential use in after-action analyses.

\subsubsection{Smoke dispersion evaluation}

There are many smoke dispersion analysis tools available online. The NIFC website discussed in Section 3.1 contains links to several of these tools, although some of the links appear to need updating. The most basic online dispersion analysis tool is the Simple Smoke Screening Tool (http://shrmc.ggy.uga.edu/maps/screen.html) provided by the Forest Service Southern Research Station. This tool automates a simple, manual, graphic screening 
method found in the Southern Smoke Management Guide. This is the tool highlighted in the NRCS "Basic Smoke Management Practices" technical note discussed in Section 3.5 (NRCS 2011), and an example output from it is shown in Figure 5. The inputs include location of burn, area of burn, fuel type, ignition method, and wind direction. This tool makes many assumptions about smoke dispersion, fuel load, and PM emission factors; it doesn't present pollutant concentration output but instead provides colored map-based output for critical smoke-impacted areas (red) and smoke-impacted areas of concern (yellow).

Figure 5. Example output from the Simple Smoke Screening Tool.*

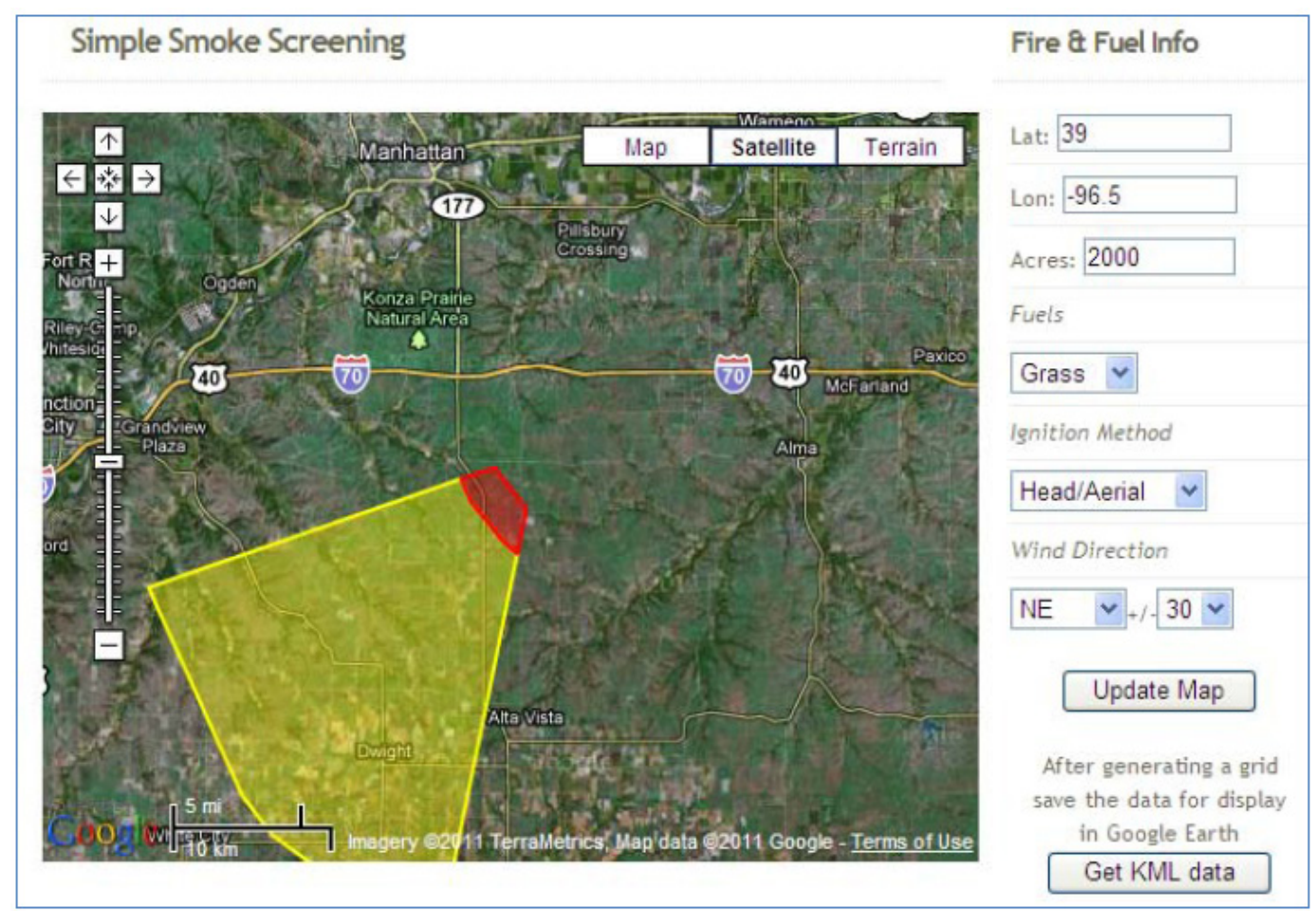

*yellow = area of concern; red = critical area

This basic level of analysis may be sufficient for many installation applications, but a specific dispersion analysis tool may be specified by state regulators such as the use of VSMOKE for some southeastern U.S. installations. Two screening-level dispersion analysis tools potentially useful to Army installations are VSMOKE-Web (http://shrmc.ggy.uga.edu/maps/vsmoke.html) 
and the BlueSky Playground (http://playground.airfire.org/). . These two tools require a greater number of inputs and, as a result, make fewer assumptions and provide greater flexibility. The decision on the level of smoke dispersion analysis will depend on the severity of smoke impacts, state requirements, and comfort level with the assumptions used and results provided by individual tools.

The smoke dispersion analysis method should be documented in the SMP portion of the IWFMP. This documentation includes explaining the source of all data inputs, the selection of smoke-sensitive areas, and the way analysis results are used in decision-making processes. It is always a good idea to include examples of smoke dispersion analysis forms, data, and results in the appendices of the IWFMP. All collected input data for smoke dispersion analysis and results data must be maintained to document the expected prescribed burn smoke impacts and for potential use in after-action analyses.

\subsection{Monitoring}

Monitoring refers to observing the effects of smoke emissions. This can include tracking the direction of smoke travel, the height the smoke plume top attains, and the amount of smoke dispersion achieved. The monitoring can be accomplished through visual observation and documented through notes, photographs, air quality monitoring data, and after-burn evaluations. Monitoring of smoke sensitive areas is particularly important. The monitoring effort should include checking the air quality of the local airshed and determining if any burn bans are in effect. Part of the Go/NoGo decision process should be an evaluation of the air quality. A common measure of air quality is the air quality index. The NIFC website discussed in Section 3.1 contains information about smoke monitoring and links to helpful websites.

Any smoke monitoring procedures should be documented in the SMP portion of the IWFMP. This documentation includes explaining the type of monitoring data collected and the method of collection. If the monitoring

\footnotetext{
* Blue Sky website requires a log-in.
} 
data is used in any decision process, the use of the smoke-monitoring data should be described. It is always a good idea to include examples of all smoke-monitoring forms, data, and results in the appendices of the IWFMP. All collected smoke monitoring data must be maintained to document the observed prescribed burn smoke impacts and for potential use in after-action analyses.

\subsection{Track fire activity}

This SMP component refers to collecting information related to the prescribed burn itself (e.g., type of fuel, area burned, location of burn, and time of ignition). The requirement to collect and store this tracking data is already included in the IWFMP through information collected in burn plans for individual prescribed fire events.

\subsection{Share the airshed/air basin}

This component of an SMP only applies to installations located in areas that occasionally experience poor air quality. "Sharing the airshed" refers to determining if other public or private landowners will be performing prescribed burns on days when the air quality may be adversely impacted by the incremental impacts of all civilian, state, and federal burn events. Army fire managers should always check the air quality index forecast (http://www.airnow.gov/) and communicate with state air-quality personnel. If applicable, procedures for checking air quality levels and contacting other organizations performing prescribed burns should be documented in the SMP portion of the IWFMP. The points of contact (POCs) responsible for prescribed burning in the region should be included in notification procedures described in Section 5.5.

\subsection{Public and installation notifications}

This SMP component refers to notifying installation and public groups about prescribed burn events. The obligation to notify relevant installation and public groups is already included in the IWFMP through requirements for site-specific burn plans. IWFMPs sometimes include a form for recording the pre-burn notifications that includes all the groups that must be contacted both on and off the installation. These groups may include the installation fire department, local community fire marshals/fire departments, range control, military police, public affairs office, state and federal 
forest managers, and state or local environmental regulators. The notifications may be made by phone, email, or posts made to a publicly available website. Table 3 shows an example of a pre-burn notification form from Fort Gordon's IWFMP. The top part of the form includes information about the date and location of the prescribed burns, followed by a list of specific contacts and their contact information. Each column is used to record information for a single burn. Blank rows are included for any additional groups that may be contacted for a specific burn.

Table 3. Public notification form example (Fort Gordon, GA).

\begin{tabular}{|c|c|c|c|c|c|}
\hline \multicolumn{6}{|c|}{ FORT GORDON PRESCRIBED BURN PHONE NOTIFICATION LOG } \\
\hline DATE & & & & & \\
\hline TA/RG NO. OR LOCATION & & & & & \\
\hline ACRES (ESTIMATE) & & & & & \\
\hline DEGREES GORDON TOWER & & & & & \\
\hline DEGREES RICHMOND TOWER & & & & & \\
\hline DEGREES COLUMBIA TOWER & & & & & \\
\hline DEGREES WRENS TOWER & & & & & \\
\hline STATE GRID BLOCK NO. & & & & & \\
\hline GFC RICHMOND COUNTY & Time & & & & \\
\hline$x x x-x x x / x x x$ & POC & & & & \\
\hline RANGE CONTROL, DPTM & Time & & & & \\
\hline$x x x-x x x / x x x$ & $\mathrm{POC}$ & & & & \\
\hline FG FIRE DEPT & Time & & & & \\
\hline$x x x-x x x / x x x$ & POC & & & & \\
\hline MP DESK & Time & & & & \\
\hline$x x x-x x x / x x x$ & POC & & & & \\
\hline MP GAME WARDENS & Time & & & & \\
\hline$x x x-x x x / x x x$ & $\mathrm{POC}$ & & & & \\
\hline BLYTHE CITY HALL & Time & & & & \\
\hline$x x x-x x x / x x x$ & POC & & & & \\
\hline BLYTHE FIRE DEPT & Time & & & & \\
\hline$x x x-x x x / x x x$ & POC & & & & \\
\hline
\end{tabular}




\begin{tabular}{|l|c|c|c|c|c|c|}
\hline \multicolumn{7}{|c|}{ FORT GORDON PRESCRIBED BURN PHONE NOTIFICATION LOG } \\
\hline GROVETOWN FIRE DEPT & Time & & & & & \\
xxx-xxx/xxx & POC & & & & & \\
\hline GA-DOC MEDICAL PRISON & Time & & & & & \\
\cline { 2 - 6 } xxx-xxx/xxx & POC & & & & & \\
\hline & Time & & & & & \\
\cline { 2 - 6 } & POC & & & & & \\
\hline CALLER'S INITIALS & & & & & & \\
\hline
\end{tabular}

\subsection{Exposure reduction}

For states/tribes, this SMP component includes exposure reduction procedures when smoke events adversely affect air quality. For Army installation-level SMPs, exposure reduction would include procedures to minimize smoke emissions when prescribed burn emissions are unexpectedly high or when weather conditions change and cause the burn emissions to drift towards smoke-sensitive receptors. The emissions causing poor air quality may be primarily from Army smoke activities, or Army prescribed burns may be a component in the cumulative effects of other prescribed burn activities in the region. The procedures to reduce emissions would include suppression of unusually high smoke-producing prescribed burns and notification of state air-quality personnel when an unusual event of this type occurs. Exposure reduction procedures must be explained in the SMP portion of the IWFMP.

\subsection{Emission reduction techniques}

This SMP component refers to the use of techniques that can limit the level and effects of emissions from prescribed burns. Some of these techniques were described in Sections 3.3 and 3.5. Key techniques to reduce the level or effects of emissions include those listed below (NWCG 2001):

1. Reduce the area burned. These techniques should not result in deferring emissions to a later date but rather, result in reducing emissions over time. These techniques have the potential to have detrimental effects on ecosystem health in fire-adapted vegetation 
community types and are therefore less applicable when prescribed burns are used to develop or maintain fire-adapted ecosystems.

a. Burn concentrations. Fuel types to be burned are concentrated in parts of the burn unit so that not all of the area is burned.

b. Fuel isolation. Fuels that have the potential to smolder (e.g., large logs, snags, deep pockets of duff, squirrel middens) are isolated so that they are not burned. Isolating these fuels can, under some circumstances, be less costly than mop-up activities that stop these fuel types from smoldering after a burn.

c. Mosaic burning. Prescribed fires that are scheduled to take advantage of the noncontinuous landscape of fuel types and fuel moistures leading to areas that are not burned.

2. Reduce fuel load. Fuel is removed, decomposed, or prevented from being produced so that there is less fuel available during prescribed burns.

a. Mechanical removal. Removal of fuel through mechanical means such as grinding, mowing, and traditional logging operations. These techniques are most useful when there is a clear use or market for the removed fuels. Mechanical removal will somewhat offset prescribed burn emission gains due to emissions from removal equipment. There is also the potential for excessive soil compaction and disturbance, stimulation of invasive nonnative plant species, removal of natural nutrient sources, and degradation of water quality.

b. Mechanical processing. Processing of dead or living vegetation into wood chips or shredded biomass. The processed material may be removed or left to decompose. Use of this technique has the potential to replace prescribed burns.

c. Firewood sales. Removal of larger-diameter logs by the public or by contractors for public sale as firewood. Army installations need to balance use of this technique with security concerns associated with civilians harvesting firewood. 
d. Biomass for electrical generation. Biomass is collected for use in cogeneration facilities located on or off the installation. This technique has the same security issues as firewood sales. Developing on-post cogeneration plants is limited due to expense and the need to obtain stationary source air permits.

e. Biomass utilization. Collection and use of woody material for nonfuel applications. These applications include pulp for paper, methanol production, wood pellets, garden bedding, and specialty forest products. Economic viability will depend on local markets. Security concerns may limit use of this technique.

f. Ungulates. Grazing of living grassy or brushy vegetation by ungulates such as sheep, cattle, or goats. Ungulates are selective in the plants they consume and may significantly change the plant species composition of ecosystems. Ungulate uses may be limited due to safety issues for the animals as related to some training missions.

3. Reduce fuel production. Techniques used to shift species composition to types that produce less biomass per year or species that are less likely to burn.

a. Chemical treatments. Use of broad-spectrum or selective herbicides to reduce living vegetation or alter species composition. This technique can reduce or eliminate the need for prescribed fire. Use of chemicals is limited by its expense and potential for environmental harm, however. A NEPA analysis will likely be required prior to implementing an herbicide application program.

b. Site conversion. Change of the vegetation types through nonchemical means such as prescribed fire. Prescribed fire use in southern pine forest can convert the understory from flammable shrubs to open woodlands, producing less total fuel generated per year.

c. Land use change. Change of wildlands to another land use category such as agricultural or urban. This technique has limited use on most Army training lands. 
4. Reduce fuel consumed. Reduction of fuel consumed during prescribed burns by scheduling burns during times when a significant portion of the fuel has a high enough moisture content to prevent combustion. However, this technique will only delay emissions if the fuel that is not consumed is still available for combustion during the next burn. The extra emissions from incomplete combustion of moist fuels are offset by the large reduction in the amount of fuel consumed. It can be difficult to use these techniques and still meet all prescribed burn program goals.

a. High moisture in large woody fuels. Burning when large-diameter woody fuels (i.e., three or more inches in diameter) are wet can result in lower fuel consumption and less smoldering.

b. Moist litter and/or duff. Limit smoldering of duff and litter layer by scheduling burns when the forest floor layer is wet. This condition most often occurs within a few days of a soaking rain or shortly after snowmelt. This technique is not useful in some fire-adapted ecosystems when one of the goals is to burn off the litter to expose soil surfaces.

c. Burn before precipitation. Scheduling prescribed burns so that precipitation events occur after the flaming phase of the burn to limit smoldering.

d. Burn before large fuels cure. In areas where trees are harvested, perform burns while the moisture content of the harvested trees is still high.

5. Schedule burn before new fuels appear. Reduction of fuel amounts by scheduling burns before the fuels appear during the burning season. This technique may interfere with land management goals of the prescribed burning program.

a. Burn before litter fall. Schedule burns before deciduous trees drop their leaves and contribute to the fuel load.

b. Burn before green-up. Schedule burns before the spring, before grasses and herbaceous fuels produce more fuel. 
6. Increase combustion efficiency. Limit the amount of smoldering to maximize the more efficient and less emission-intensive flaming stage.

a. Burn piles or windrows. Concentrating fuels into clean and dry piles or windrows for more efficient combustion. Piles and windrows that are wet or contain soil can results in significant smoldering. This technique is limited by the cost and emissions from heavy equipment.

b. Backing fires. Produce more efficient, lower-emitting burns by using a backing fire instead of a heading fire. In general, backing fires produce more efficient combustion since the flame front passes more slowly across the unit being burned when compared to a heading fire.

c. Dry conditions. Schedule burns during dry condition to produce more efficient combustion conditions. This technique is only applicable when burns will consume the same amount of fuel as during wet conditions. As noted above, when conditions are wet, the lower fuel consumption generally more than offsets any emission reductions from more efficient combustion.

d. Rapid mop-up. Rapid extinguishing of smoldering fuels after a burn. This technique is limited by its cost.

e. Aerial ignition/mass ignition. Large-scale ignition of prescribed burns through using a helitorch or other aerial-based method. A large-scale, more sudden ignition process generally results in a more rapid consumption of dry surface fuel and generation of highly convective plumes. This type of plume draws heat away from the fuelbed and prevents drying and preheating of larger and moister fuels. Under most meteorological conditions, these plumes will rapidly rise and thus, will more effectively disperse emissions.

f. Air curtain incinerators. Burning of fuels in a large container or pit with the aid of a powerful blower that forces air into the fire. These incinerator devices create very efficient combustion with little visible smoke emissions. Because of their cost, they are usually only 
employed during large-scale land clearing conducted near smokesensitive areas.

7. Redistribute the emissions. Air quality problems and complaints can be prevented by burning during periods of good atmospheric dispersion and when prevailing winds will transport emission away from sensitive areas. Tools for gathering meteorological data and performing dispersion assessments were discussed in Section 5.1.

a. Burn when dispersion is good. Unstable atmospheric condition will more rapidly dilute prescribed burn emissions when compared to emissions released during more stable atmospheric conditions. Unstable conditions will also induce greater plume rise that can transport plumes over sensitive areas.

b. Share the airshed. Establishing local and regional communications about prescribed burn events can prevent multiple large burns that would cause smoke impacts.

c. Avoid sensitive areas. Burns should not be scheduled when winds are expected to transport burn emissions towards sensitive areas. The use of a dispersion model as discussed in Section 5.1.2 can help determine if sensitive areas may experience adverse smoke impacts.

d. Burn smaller units. Short-term emission impacts can sometimes be avoided by burning a subset of the scheduled units on days with challenging meteorological conditions.

e. Burn more frequently. Burning units on a more frequent schedule will result in less fuel generation between burns and therefore, fewer emissions each time the unit is burned. However, more frequent burns would require that more acreage is burnt each year across the installation to keep up with the faster return intervals. It is therefore not clear that annual emission amounts would be reduced by burning more frequently.

Table 4 shows some of the constraints including the relative cost for each of the smoke management practices discussed above. The chosen mixture of these techniques will depend on many factors including the size of the 
prescribed burn program, locations of smoke-sensitive areas, installation missions, security requirements, the level of regional prescribed burn activity, air quality of the region, and state/local air quality requirements for prescribed burning.

Emission reduction techniques are most valuable when they can be related to the amount of emission reduction. If the technique reduces fuel, then the emission reduction can be related directly to the amount of fuel reduction. For other techniques, the emission reduction estimation is not as straightforward. There is some information on emission reductions presented in the NWCG Smoke Management Guide (NWCG 2001). A table from the document is shown in Table 5 . This information provides only a rough guide to potential reductions since it is an estimate from the Consume 2.1 model which is based on very specific conditions. Reductions shown in Table 5 are for individual burns and may not always relate to emission reduction across an entire burning season.

Great care must be taken when applying emission reduction techniques. Many of these techniques have the potential to limit plume rise and therefore limit plume dispersion. Other techniques limiting fuel consumption in moist conditions may increase the smoldering of fuels. Local experience with the application of these techniques is crucial. The SMP portion of the IWFMP must document the use of smoke management techniques to show which smoke management practices are being applied. 

Table 4. Constraints and relative costs for smoke
management practices (NWCG 2001).

\begin{tabular}{|c|c|c|c|c|c|}
\hline \multirow{2}{*}{$\begin{array}{c}\text { Smoke Management } \\
\text { Method }\end{array}$} & \multicolumn{5}{|c|}{ 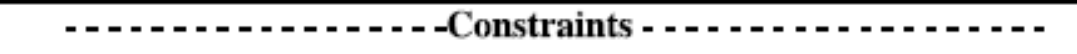 } \\
\hline & Administrative & Physical & Legal & Cost & Other \\
\hline \multicolumn{6}{|l|}{ 1. Reduce the Area Burned } \\
\hline - Burn Concentrations & Few & $\begin{array}{l}\text { Slope and } \\
\text { Access }\end{array}$ & Few & High & $\begin{array}{l}\text { Only applicable to small } \\
\text { pockets of fuel }\end{array}$ \\
\hline - $\quad$ Isolate Fuels & Few & Slope & Few & High & Incompatible fuels \\
\hline - $\quad$ Mosaic Burning & Few & Few & Few & Moderate & Incompatible fuels \\
\hline \multicolumn{6}{|l|}{ 2. Reduce Fuel Load } \\
\hline - Mechanical Removal & Moderate & Slope & Few & Moderate & Slope \\
\hline - Mechanical Processing & Moderate & $\begin{array}{l}\text { Slope and } \\
\text { Access }\end{array}$ & Few & High & Incompatible fuels \\
\hline - $\quad$ Firewood Sales & High & Access & High & Few & No markets, incompatible fuels \\
\hline $\begin{array}{l}\text { - } \\
\text { Biomass for Electrical } \\
\text { Generation }\end{array}$ & High & $\begin{array}{c}\text { Slope and } \\
\text { Access }\end{array}$ & Moderate & High & No markets, incompatible fuels \\
\hline - Biomass Utilization & High & $\begin{array}{l}\text { Slope and } \\
\text { Access }\end{array}$ & Moderate & High & No markets, incompatible fuels \\
\hline - Ungulates & Few & Few & High & High & Incompatible fuels \\
\hline \multicolumn{6}{|l|}{ 3. Reduce Fuel Production } \\
\hline - Chemical Treatment & High & Few & Very High & Very High & $\begin{array}{c}\text { Controversial policy, adverse } \\
\text { water quality impacts }\end{array}$ \\
\hline - $\quad$ Site Conversion & High & Few & High & High & Ecosystem impacts \\
\hline - $\quad$ Land Use Change & Very High & Few & Very High & Very High & Ecosystem impacts \\
\hline \multicolumn{6}{|l|}{ 4. Reduce Fuel Consumed } \\
\hline $\begin{array}{l}\text { High Moisture in Large } \\
\text { Woody Fuels }\end{array}$ & Few & Few & Few & Few & $\begin{array}{c}\text { Incompatible fuels in some } \\
\text { regions }\end{array}$ \\
\hline - $\quad$ Moist Litter and Duff & Few & Few & Few & Few & Not used in the SW region \\
\hline - $\quad$ Burn Before Precipitation & Few & None & None & Few & Difficult to plan \\
\hline $\begin{array}{l}\text { Burn Before Large Fuels } \\
\text { Cure }\end{array}$ & Few & Few & Few & Few & $\begin{array}{l}\text { Limited to activity fuels, } \\
\text { incompatible fuel types }\end{array}$ \\
\hline \multicolumn{6}{|c|}{ 5. Schedule Burning Before New Fuels Appear } \\
\hline - Burn Before Litter Fall & Few & Few & None & Few & $\begin{array}{l}\text { Incompatible fuels in most } \\
\text { regions }\end{array}$ \\
\hline - $\quad$ Burn Before Green-Up & Few & Slope & Few & Few & Limited use in many fuel types \\
\hline \multicolumn{6}{|l|}{ 6. Increase Combustion Efficiency } \\
\hline - $\quad$ Burn Piles and Windrows & FcW & Slope & Few & High & \\
\hline - $\quad$ Backing Fires & Few & $\begin{array}{c}\text { Fuel } \\
\text { continuity }\end{array}$ & Few & Few & $\begin{array}{l}\text { Need correct meteorological } \\
\text { conditions }\end{array}$ \\
\hline - Dry Conditions & High & $\begin{array}{c}\text { Dry } \\
\text { conditions }\end{array}$ & High & High & Increased escape potential \\
\hline - Rapid Mop-Up & Few & $\begin{array}{l}\text { Slope and } \\
\text { access }\end{array}$ & Few & High & \\
\hline $\begin{array}{l}\text { Aerial Ignition/Mass } \\
\text { Ignition }\end{array}$ & Few & Few & Few & Moderate & $\begin{array}{l}\text { Trained crews and equipment; } \\
\text { fuel types }\end{array}$ \\
\hline - $\quad$ Air Curtain Incinerators & Few & Access & Few & Very high & \\
\hline \multicolumn{6}{|l|}{ 7. Redistribute Emissions } \\
\hline $\begin{array}{l}\text { Burn When Dispersion is } \\
\text { Good }\end{array}$ & Few & Moderate & Few & Moderate & Increased escape potential \\
\hline - Share the Airshed & High & Few & High & High & \\
\hline - $\quad$ Avoid Sensitive Areas & Few & Moderate & Few & High & \\
\hline - $\quad$ Burn Smaller Units & High & Few & Few & High & \\
\hline - $\quad$ Burn More Frequently & Few & Few & Few & Moderate & $\begin{array}{l}\text { Smoke management windows } \\
\text { and cost }\end{array}$ \\
\hline
\end{tabular}


Table 5. Approximate emission reduction effectiveness for emission reduction techniques used on specifc vegetation types (NWCG 2001).

\begin{tabular}{|c|c|c|c|c|c|c|c|c|c|c|c|c|}
\hline $\begin{array}{l}\text { Emission } \\
\text { Reduction } \\
\text { Technique }\end{array}$ & Vegetation Type & $\begin{array}{c}\text { Total Fuel } \\
\text { Loading } \\
\text { (tons/acre) }\end{array}$ & $\begin{array}{l}\text { Fuel } \\
\text { Type }^{1}\end{array}$ & $\begin{array}{l}\text { Size } \\
\text { (acres) }\end{array}$ & $\begin{array}{l}\underset{\text { Ignition }}{\text { Time }} \\
\text { (minutes) }^{2}\end{array}$ & $\begin{array}{c}\text { Large Fuel } \\
\text { Moisture } \\
\text { (percent) }\end{array}$ & $\begin{array}{c}\text { Duff } \\
\text { Moisture } \\
\text { (percent) }\end{array}$ & $\begin{array}{c}\text { Total Fuel } \\
\text { Consumption } \\
\text { (tons) }\end{array}$ & $\begin{array}{l}\text { Total } \mathbf{P M}_{1 \mathrm{n}} \\
\text { Emissions } \\
\text { (tons) }\end{array}$ & $\begin{array}{c}\text { PM10 } \\
\text { Emission } \\
\text { Reduction } \\
\text { (percent) }\end{array}$ & $\begin{array}{c}\text { Total } \mathbf{P M}_{2 \mathrm{~s}} \\
\text { Emissions } \\
\text { (tons) }\end{array}$ & $\begin{array}{c}\mathbf{P M}_{2,5} \\
\text { Emission } \\
\text { Reduction } \\
\text { (percent) }\end{array}$ \\
\hline Mosaic Burning & Southern pine & 10.9 & Natural & 100 & 180 & N/A & 120 & 296 & 3.09 & \multirow[b]{2}{*}{50} & 2.95 & \multirow[b]{2}{*}{50} \\
\hline $\begin{array}{l}\text { Non-mosaic } \\
\text { Burning }\end{array}$ & Southern pine & 10.9 & Natural & 200 & 180 & N/A & 120 & 593 & 6.19 & & 5.91 & \\
\hline $\begin{array}{c}\text { Mechanical } \\
\text { removal }\end{array}$ & $\begin{array}{c}\text { North central red and } \\
\text { white pine }\end{array}$ & 19.4 & Activity & 100 & 180 & 30 & N/A & 1,659 & 15.65 & \multirow{2}{*}{40} & 14.82 & \multirow{2}{*}{42} \\
\hline $\begin{array}{c}\text { No Mechanical } \\
\text { removal }\end{array}$ & $\begin{array}{l}\text { North central red and } \\
\text { white pine }\end{array}$ & 32.4 & Activity & 100 & 180 & 30 & N/A & 2,531 & 26.42 & & 25.56 & \\
\hline Ungulates & Midwest grassland & 1.0 & Natural & 100 & N/A & N/A & 120 & 17 & 0.17 & \multirow[t]{2}{*}{70} & 0.06 & \multirow{2}{*}{67} \\
\hline No Ungulates & Midwest grassland & 1.4 & Natural & 100 & $\mathrm{~N} / \mathrm{A}$ & N/A & 120 & 57 & 0.57 & & 0.18 & \\
\hline $\begin{array}{l}\text { High Moisture in } \\
\text { Large Fuels }\end{array}$ & Interior mixed conifer & 96.9 & Activity & 100 & 180 & 40 & $\mathrm{~N} / \mathrm{A}$ & 3,924 & 34.92 & \multirow{2}{*}{44} & 32.65 & \multirow{2}{*}{43} \\
\hline $\begin{array}{c}\text { Low Moisture in } \\
\text { Large Fuels }\end{array}$ & Interior mixed conifer & 96.9 & Activity & 100 & 180 & 15 & $\mathrm{~N} / \mathrm{A}$ & 7,270 & 62.33 & & 57.67 & \\
\hline $\begin{array}{l}\text { Moist Litter and/or } \\
\text { Duff }\end{array}$ & Alaska black spruce & 30.8 & Natural & 100 & N/A & N/A & 120 & 1,492 & 13.19 & \multirow{2}{*}{26} & 12.39 & \multirow{2}{*}{26} \\
\hline $\begin{array}{l}\text { Dry Litter and/or } \\
\text { Duff }\end{array}$ & Alaska black spruce & 30.8 & Natural & 100 & N/A & N/A & 40 & 1,909 & 17.83 & & 16.85 & \\
\hline $\begin{array}{l}\text { Burn Before Large } \\
\text { Fuels Cure }\end{array}$ & $\begin{array}{c}\text { Pacific Northwest } \\
\text { Douglas-fir/hemlock }\end{array}$ & 118.6 & Activity & 100 & 180 & 100 & N/A & 3,165 & 24.82 & \multirow{2}{*}{45} & 22.47 & \multirow{2}{*}{44} \\
\hline $\begin{array}{l}\text { Burn After Large } \\
\text { Fuels Cure }\end{array}$ & $\begin{array}{c}\text { Pacific Northwest } \\
\text { Douglas-fir/hemlock }\end{array}$ & 118.6 & Activity & 100 & 180 & 30 & N/A & 6,194 & 45.21 & & 40.10 & \\
\hline Piled Fuels & $\begin{array}{l}\text { Southwest Ponderosa } \\
\text { pine }\end{array}$ & 43.2 & Piled & 100 & N/A & N/A & $\mathrm{N} / \mathrm{A}$ & 8,549 & 31.16 & \multirow{2}{*}{9} & 27.14 & \multirow{2}{*}{13} \\
\hline Non-piled Fuels & $\begin{array}{c}\text { Southwest Ponderosa } \\
\text { pine }\end{array}$ & 44.6 & Activity & 100 & 180 & 30 & N/A & 2,672 & 34.16 & & 31.34 & \\
\hline Mass Ignition & $\begin{array}{c}\text { Pacific Northwest } \\
\text { Douglas-fir/hemlock }\end{array}$ & 118.6 & Activity & 100 & 30 & 40 & N/A & 5,597 & 40.77 & \multirow[b]{2}{*}{10} & 36.13 & \multirow{2}{*}{10} \\
\hline No Mass Ignition & $\begin{array}{c}\text { Pacific Northwest } \\
\text { Douglas-fir/hemlock }\end{array}$ & 118.6 & Activity & 100 & 180 & 40 & N/A & 6,195 & 45.21 & & 40.10 & \\
\hline $\begin{array}{l}\text { Burn More } \\
\text { Frequently }\end{array}$ & California chaparral & 6.7 & Natural & 100 & N/A & N/A & 120 & 469 & 3.87 & \multirow{2}{*}{83} & 3.17 & \multirow{2}{*}{83} \\
\hline $\begin{array}{l}\text { Burn Less } \\
\text { Frequently }\end{array}$ & California chaparral & 39.7 & Natural & 100 & N/A & $\mathrm{N} / \mathrm{A}$ & 120 & 2,779 & 22.93 & & 18.76 & \\
\hline
\end{tabular}

Activity fuels are woody debris resulting from management activity such as loggin

A tractor piled unit does not require ignition time for Consume 2.1 .

A nalural fuel thil or piled unil does not require large woody fuel moisture content input for Consume 2.1

${ }^{4}$ An activity fuel units or piled unit does not require duff moisture content input for Consume 2.1 


\subsection{Documentation}

As mentioned in each of the preceding sections, it is extremely important to describe procedures used to manage emissions from prescribed burns and to maintain records of prescribed burn events. The historic records should be maintained as long as is reasonably possible. The records are useful for improving prescribed burn smoke management programs after learning lessons from unexpected adverse smoke impacts. The records may also be requested by air quality regulators to demonstrate if an Army burn could be classified as an exceptional event.

\subsection{Public education}

This component of SMPs is relevant to all installations and especially those that have received complaints regarding prescribed burn smoke emissions. Public education and information plays a vital role in prescribed burning and wildland fire use. This role may become more critical as encroachment causes greater public exposure to prescribed fire smoke. Without education, the public will not understand the vital role prescribed burns play in land management.

Several techniques can be employed to describe the purpose and benefits of an installation's prescribed burn program. Public outreach can include hosting open houses, holding public meetings with stakeholders when major changes to prescribed burn program are anticipated, distributing press releases, creating brochures, and maintaining information on publicly accessible websites.

There are many resources available online to help develop public education materials. Several examples are presented below.

State-prescribed fire council websites are good sources of educational material. For example, the North Carolina's Prescribed Fire Council resources site that links to useful public education materials: http://www.ncprescribedfirecouncil.org/resources.html.

The Southern Fire Exchange is another example of a website with public education resources: http://southernfireexchange.org/SFE_Publications/Public_Education.html.

Videos can also be a powerful way to illustrate the benefits of prescribed burn programs. The National Coalition of Prescribed Fire Councils website 
contains the following links to videos discussing the benefits of prescribed fire:

Video - A Land in Balance: Benefits of Prescribed Fire Use

Video - Why Burn? Fire in the Great Plains

Video - Prescribed Fire: It's Time

The Public Affairs Officer (PAO) should be involved in developing the required educational materials. Printed material can be made available in public forums, including land management planning meetings. Any public education programs should be explained in the SMP portion of the IWFMP.

\subsection{Burn authorization}

State/tribal SMPs normally contain procedures to authorize planned prescribed burn events before their occurrence. In states with high prescribed burn activity, the authorization is likely implemented through a permit system. Permits for individual burns are issued after a review of prescribed burn plan information that is submitted to the state/tribe.

As was discussed in Section 5.5, Army installations should have a process for informing state air quality regulators (and other relevant organizations) when burn events will occur. There should also be clear procedures on the installation for internal authorization of prescribed burns. The procedures should describe levels of authority, roles of prescribed burn personnel, and the factors included in deciding to proceed with burns. All of burn authorization procedures must be included in the SMP portion of the IWFMP.

Agencies belonging to the NWCG (e.g., USFS, BLM, NPS, and BIA) use two forms (PMS 485 and PMS 486) that could serve as a starting point for developing Army installation templates for documenting burn authorization procedures and actions. These forms are part of the Interagency Prescribed Fire Plan Template (Part 2A and Part 2B) shown in Appendix A. These forms are also shown Figure 6 and Figure 7.

The first form (PMS 485; Figure 6) is used to acquire agency approval of prescribed burn plans. This form is approved well before ignition, and it contains a range of dates for implementing the prescribed burn program. 
PMS 485 includes discussion elements that must be considered part of the general prescribed burn planning and decision making process. Although this form covers all aspects of prescribed burn authorization, all of the items on the form are also part of smoke management planning and decision making.

The second form (Figure 7), PMS 486, is used to document the steps taken to allow ignition of a specific prescribed burn. The form presents important decision points in the form of a "Yes or No" checklist where any "No" answer results in a No-Go decision for the burn. The form covers all aspects of prescribed burn decision making including smoke management. For smoke management, the form covers areas discussed in Sections 5.1, $5.4,5.5,5.7$, and 5.8 regarding smoke effects analysis, required notifications, adherence to smoke management practices, and documentation.

If there are specific conditions that must be met regarding fuel (e.g., moisture content), meteorology (e.g., wind direction and atmospheric stability), or air quality (e.g., high air-quality index), it is useful to include these values on a Go/No-Go checklist form. This can greatly reduce the likelihood of smoke impacts on smoke-sensitive areas (e.g., highways, runways, schools, health facilities, on- and off-post housing areas, Class I areas, and nonattainment areas). Figure 8 shows an example of this type of checklist, used at Fort Gordon. 
Figure 6. Agency Administrator Ignition Authorization, form PMS 485, used by agencies in the NWCG (NWGC 2014).

Project Name:

Unit Name:

\section{AGENCY ADMINISTRATOR IGNITION AUTHORIZATION (Prescribed Fire Plan, Element 2A)}

Instructions: The Agency Administrator Ignition Authorization must be completed before a prescribed fire can be implemented. If ignition of the prescribed fire is not initiated prior to expiration date determined by the agency administrator, a new authorization will be required.

Prior to signature the agency administrator should discuss the following key items with the fire management officer (FMO) or bum boss. Attach any additional instructions or discussion documentation (optional) to this document.

Key Discussion Items

A. Has anything changed since the Prescribed Fire Plan was approved or revalidated?

Such as drought or other climate indicators of increased risk, insect activity, new subdivisions/structures, smoke requirements, Complexity Analys is Rating.

B. Have compliance requirements and pre-burn considerations been completed?

Such as preparation work, NEPA mitigation requirements, cultural, threatened and endangered species, smoke permits, state burn permits/authorizations.

C. Can all of the elements and conditions specified in Prescribed Fire Plan be met?

Such as weather, scheduling, smoke management conditions, suitable prescription window, correct season, staffing and organization, safety consider ations, etc.

D. Are processes in place to ensure all internal and external notifications and media releases will be completed?

E. Have key agency staffs been fully briefed about the implementation of this prescribed fire?

F. Are there circumstances that could affect the successful implementation of the plan? Such as preparedness level restrictions, resource availability, other prescribed fire or wildfire activity

G. Have you communicated your expectations to the Bum Boss and FMO regarding if and when you are to be notified that contingency actions are being taken?

H. Have you communicated your expectations to the Bum Boss and FMO regarding decisions to declare the prescribed fire a wildfire?

Implementation Recommended by:

FMO or Prescribed Fire Bum Boss Signature: Date:

I am authorizing ignition of this prescribed fire between the dates of and It is my expectation that the project will be implemented within this time frame and as discussed and documented and attached to this plan. If the conditions we discussed change during this time frame, it is my expectation you will brief me on the circumstances and an updated authorization will be negotiated if necessary.

Additional Instructions or Discussion Documentation attached (Optional): Yes $\square$ No $\square$ Ignition Authorized by: Agency Administrator Signature and Title: Date:

PMS 485 (11/13) 
Figure 7. Prescribed fire go/no-go checklist, form PMS 486, used by agencies in the NWCG (NWGC 2014).

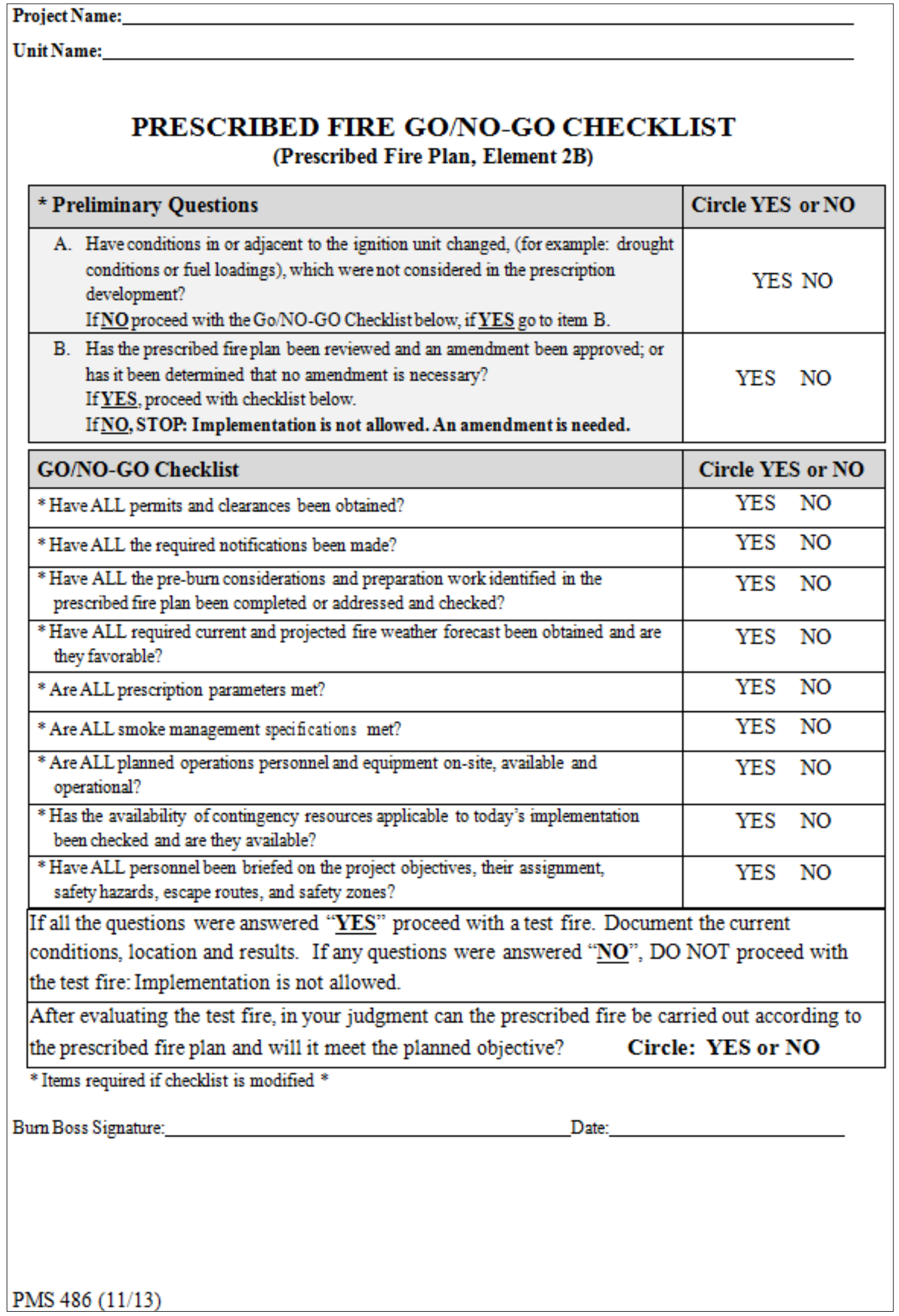


Figure 8. Prescribed fire pre-burn checklist used by Fort Gordon*.

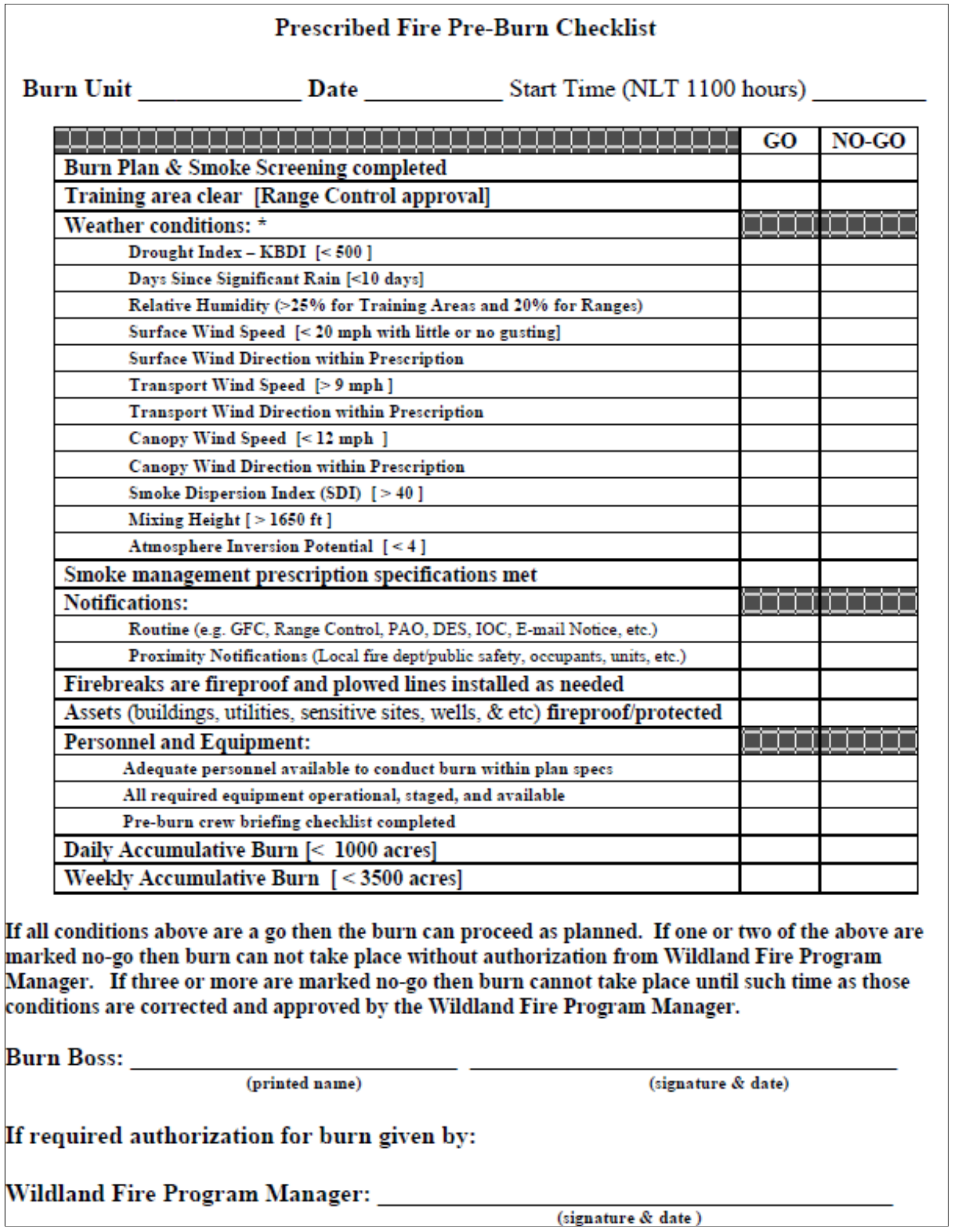

* KBDI = Keetch-Byram Drought Index, GFC = Georgia Forestry Commission, DES $=$ Directorate of Emergency Services, and IOC = Installation Operation Center. 


\subsection{Surveillance and enforcement}

State/tribal SMPs normally contain mechanisms to assure compliance with SMP requirements. Installation-level SMPs expressed in the IWFMP should contain descriptions of key personnel's roles and responsibilities for prescribed burn plan execution. There should be procedures in place that allow responsible employees to ensure that requirements have been met.

\subsection{Program evaluation}

IWFMPs are required to be reviewed and updated annually and revised at least once every five years. Therefore, the evaluation component of SMPs is automatically met.

\subsection{List regulatory requirements}

The "Smoke Management and Air Quality" section of an IWFMP is required to include applicable state and local permit reporting requirements which are specific to the installation and region that affect smoke management. This section must include all state air quality regulations applicable to prescribed fire smoke emissions and any requirements in the state's SMP.

\subsection{Training}

Installations should have specific training requirements or certifications for personnel involved with prescribed burning. Training requirements should be included in the IWFMP. Smoke management training links can be found on the NIFC website described in Section 3.1. Training shown for smoke management on this site is available through formal and online courses, as shown below. Training specific to managing emissions from prescribed burns should be documented in the SMP portion of the IWFMP.

There are several formal courses offered through the national training center that include smoke management in the curriculum. However, RX-410 specifically focuses on smoke management training.

- RX-301 - Prescribed Fire Implementation

- RX-310 - Introduction to Fire Effects

- RX-341 - Prescribed Fire Burn Plan Preparation 
- RX-410 - Smoke Management Techniques

- RX-510 - Applied Fire Effects

Go to the National Wildland Fire Training website to schedule training in these formal courses, as it is made available:

http://www.nationalfiretraining.net/schedule/list

There are also two online course site links shown on the training page of the NIFC website. Updated links for these two training sites are shown below. The specific training on the NIFC website may change over time, however, as information is updated.

- EPA Air Pollution Training Institute

http://www.apti-learn.net/LMS/EPAHomePage.aspx

- Smoke Management and Air Quality for Land Managers

https://www.frames.gov/partner-sites/emissions-and-smoke/educational-resources/tutorial/ 


\section{Summary and Recommendations}

EPA has the authority to regulate prescribed fire emissions through the CAA. Its policy on controlling emissions from wildland fires is complex and still evolving. Smoke emissions are regulated because they contribute to exceedances of the $\mathrm{PM}_{2.5}$ NAAQS, the ozone NAAQS, and visibility degradation in Class I areas. In its interim policy, EPA recognized the many benefits of using fire for land management and presented a control strategy based on states/tribes developing SMPs. The interim guidance provided required sections for SMPs to allow certification of state/tribal SMPs by the EPA. EPA rules for controlling smoke emission impacts on visibility degradation in Class I areas and classifying some fire events as exceptional events expanded on this theme of balancing wildland fire's benefits against wildland fire's large contribution to $\mathrm{PM}_{2.5}$ emissions in many areas.

States have implemented EPA regulations and policy by developing their own regulations, SMPs, and SIP conditions. The complexity and level of control varies widely among states. Some regional consistency exists in the approach for controlling fire emissions to prevent visibility degradation because of the establishment of RPOs.

A wide array of guidance for developing SMPs and tools for managing prescribed fire emissions is available. Much of this guidance and many of these tools have been developed by federal agencies or consortiums of federal agencies (e.g., NWCG). This information and many of the tools are applicable to Army installation management of prescribed burn smoke emissions.

The Army already has the basic framework for developing SMPs within an installation's IWFMP. The IWFMPs already requires information on smoke management, but this information is often scattered throughout IWFMPs and is sometimes difficult to recognize as a coherent SMP.

One approach for developing Army SMPs is to follow the required elements of state/tribal SMPs. If this approach is taken, it is recommended that Army SMPs contain the following sections: 
- Meteorology and Smoke Dispersion Evaluation

- Monitoring

- Track Fire Activity

- Share the Airshed/Air Basin

- Public and Installation Notification

- Exposure Reduction

- Emission Reduction Techniques

- Documentation

- Public Education

- Burn Authorization

- Surveillance and Enforcement

- Program Evaluation

It is also recommended that a great deal of flexibility be allowed in installation SMPs. Installation smoke management requirements will vary greatly due to the extreme variations among installations in the use of prescribed fire, the impacts of smoke emissions on smoke-sensitive areas, and the applicable state's air-quality regulatory requirements for controlling these emissions. 


\section{References}

Barnard, William S. and Edward Sabo. 2008. Documentation of the Base G2 and Best \& Final 2002 Base Year, 2009, and 2018 Emission Inventories for VISTAS. Prepared for Visibility Improvement State and Tribal Association of the Southeast. Alpharetta, GA: MACTEC Engineering and Consulting, Inc.

DoD (Department of Defense). 2011. "Natural Resources Conservation.” Department of Defense Instruction (DoDI) 4715.03. Washington, DC: Office of the Under Secretary of Defense for Acquisition, Technology, and Logistics (OUSD(AT\&L). http://www.dtic.mil/whs/directives/corres/pdf/471503p.pdf

Miller, Wayne. 2013. "New tools for Estimating and Managing Local/Regional Air Quality Impacts of Prescribed Burns. SERDP Project RC-1648.” Alexandria, VA: Strategic Environmental Research and Development Program. https://www.serdpestcp.org/Program-Areas/Resource-Conservation-and-Climate-Change/Air-Quality/RC-1648

National Coalition of Prescribed Fire Councils. 2007. "The National Coalition of Prescribed Fire Councils Guide to Smoke Management.” Coalition of Prescribed Fire Councils, Inc. (www.prescribedfire.net) http://www.garxfire.com/pdf\%20files/The_National_Coalition_of_Prescribed_Fire_Councils_Gu ide_to_Smoke_Management.pdf

NIFC. 2008. "Guidance for After Action Review of Smoke Impacts." Boise, ID: National Interagency Fire Center. http://www.nifc.gov/programs/programs_sm_tools_aar.html

NRCS. 2011. "Basic Smoke Management Practices.” Technical note. Washington, DC: U.S. Department of Agriculture, National Resources Conservation Service. http://www.nrcs.usda.gov/Internet/FSE_DOCUMENTS/stelprdb1046311.pdf

NWCG. 2001. Smoke Management Guide for Prescribed and Wildland Fire. Boise, ID: National Wildfire Coordinating Group, Technical Smoke Topics Committee. http://www.nwcg.gov/sites/default/files/products/pms420-2.pdf . 2003. Interagency Strategy for the Implementation of Federal Wildland Fire Management Policy. Boise, ID: National Wildfire Coordinating Group. http://www.sierraforestlegacy.org/Resources/Community/SmokeManagement/ AirQualityPolicy/FedWldFireMgmtPolicy.pdf

. 2014. Interagency Prescribed Fire Planning and Implementation Procedures Guide. PMS 484. Boise, ID: National Wildfire Coordinating Group, Fire Use Subcommittee. http://www.nwcg.gov/sites/default/files/products/pms484.pdf.

Pacific Northwest Regional Laboratory (with named authors). 2013. Advanced Chemical Measurements of Smoke from DoD-Prescribed Burns. SERDP Project RC-1649. Alexandria, VA: Strategic Environmental Research and Development Program. https://www.serdp-estcp.org/Program-Areas/Resource-Conservation-and-Climate-Change/AirQuality/RC-1649 
U.S. Army. 2002. Army Wildland Fire Policy Guidance. Washington, DC: Department of the Army, Assistant Chief of Staff for Installation Management.

http://www.aec.army.mil/Portals/3/conserve/Guidance_ACSIM_Wildland_Fire_Policy_2002.p df.

U.S. Army. 2004. "The Army Strategy for the Environment: Sustain the Mission-Secure the Future." Washington, DC: Department of the Army. http://www.aepi.army.mil/publications/strategicpolicy/ http://www.asaie.army.mil/Public/ESOH/doc/ArmyEnvStrategy.pdf . 2007 "Environmental Protection and Enhancement." AR 200-1. Washington, DC: Department of the Army. . 2011. Army Threatened and Endangered Species, FY10. Washington, DC: Department of the Army, Office of the Chief of Staff for Installation Management (OACSIM).

U.S. Congress. 1970. “The Clean Air Act.” Public Law (P.L.) 91-604, 31. Washington, DC: U.S. Congress.

. 1973. "Endangered Species Act of 1973." P.L. 93-205. Washington, DC: U.S. Congress. http://legislink.org/us/pl-93-205.

. 1990. "Clean Air Act Amendments of 1990." P.L. 101-549. Washington, DC: U.S. Congress.

U.S. EPA. 1998. "Interim Air Quality Policy on Wildland and Prescribed Fires." http://www.epa.gov/ttn/oarpg/t1/memoranda/firefnl.pdf. . 1999. "Regional Haze Regulations: Final Rule." 40 CFR Part 51. Federal Register 64(126): 35714-35774.Washington, DC: U.S. Environmental Protection Agency.

.2007. "Treatment of Data Influenced by Exception Events Rule: Final Rule." 40 CFR Parts 50 and 51. Federal Register 72(55): 13560-13581. Washington, DC: U.S. Environmental Protection Agency. https://federalregistergov/a/E7-5156. 


\title{
Appendix A: Interagency Prescribed Fire Plan Template (from NWCG 2014)
}

\section{Element 1: Signature page}

\author{
PRESCRIBED FIRE PLAN
}

ADMINISTRATIVE UNIT NAME(S):

PRESCRIBED FIRE NAME:

Prescribed Fire Unit (Ignition Unit):

PREPARED BY:

Name (print): Qualification/Currency:

Signature: Date:

TECHNICAL REVIEW BY:

Name (print): Qualification/Currency:

Signature: Date:

COMPLEXITY RATING:

MINIMUM BURN BOSS QUALIFICATION:

APPROVED BY:

Name - Agency Administrator (print):

Signature - Agency Administrator: Date: 


\title{
AGENCY ADMINISTRATOR IGNITION AUTHORIZATION
}

\author{
(Prescribed Fire Plan, Element 2A)
}

Instructions: The Agency Administrator Ignition Authorization must be completed before a prescribed fire can be implemented. If ignition of the prescribed fire is not initiated prior to expiration date determined by the agency administrator, a new authorization will be required.

Prior to signature the agency administrator should discuss the following key items with the fire management officer (FMO) or burn boss. Attach any additional instructions or discussion documentation (optional) to this document.

Key Discussion Items
A. Has anything changed since the Prescribed Fire Plan was approved or revali- dated?
Such as drought or other climate indicators of increased risk, insect activity, new subdivisions/structures, smoke requirements, Complexity Analysis Rat- ing.

B. Have compliance requirements and pre-burn considerations been completed?

Such as preparation work, NEPA mitigation requirements, cultural, threatened and endangered species, smoke permits, state burn permits/authorizations.

C. Can all of the elements and conditions specified in Prescribed Fire Plan be met?

Such as weather, scheduling, smoke management conditions, suitable prescription window, correct season, staffing and organization, safety considerations, etc.

D. Are processes in place to ensure all internal and external notifications and media releases will be completed?

E. Have key agency staffs been fully briefed about the implementation of this prescribed fire?

F. Are there circumstances that could affect the successful implementation of the plan?

Such as preparedness level restrictions, resource availability, other prescribed fire or wildfire activity 
G. Have you communicated your expectations to the Burn Boss and FMO regarding if and when you are to be notified that contingency actions are being taken?

H. Have you communicated your expectations to the Burn Boss and FMO regarding decisions to declare the prescribed fire a wildfire?

Implementation Recommended by:

FMO or Prescribed Fire Burn Boss Signature:

Date:

I am authorizing ignition of this prescribed fire between the dates of and

It is my expectation that the project will be implemented within this time frame and as discussed and documented and attached to this plan. If the conditions we discussed change during this time frame, it is my expectation you will brief me on the circumstances and an updated authorization will be negotiated if necessary.

Additional Instructions or Discussion Documentation attached (Optional): Yes $\square$ No $\square$ Ignition Authorized by:

Agency Administrator Signature and Title: Date: 


\section{PRESCRIBED FIRE GO/NO-GO CHECKLIST}

\section{(Prescribed Fire Plan, Element 2B)}

\section{* Preliminary Questions}

Circle YES or NO

A. Have conditions in or adjacent to the ignition unit changed, (for example: drought conditions or fuel loadings), which were not considered in the prescription development?

If NO proceed with the Go/NO-GO Checklist below, if YES go to item B.

B. Has the prescribed fire plan been reviewed and an amendment been approved; or has it been determined that no amendment is necessary? If YES, proceed with checklist below. If NO , STOP: Implementation is not allowed. An amendment is needed.

\begin{tabular}{|l|c|}
\hline GO/NO-GO Checklist & Circle YES or NO \\
\hline * Have ALL permits and clearances been obtained? & YES NO \\
\hline * Have ALL the required notifications been made? & YES NO \\
\hline $\begin{array}{l}\text { * Have ALL the pre-burn considerations and preparation work identified } \\
\text { in the prescribed fire plan been completed or addressed and checked? }\end{array}$ & YES NO \\
\hline $\begin{array}{l}\text { * Have ALL required current and projected fire weather forecast been obtained } \\
\text { and are they favorable? }\end{array}$ & YES NO \\
\hline * Are ALL prescription parameters met? & YES NO \\
\hline * Are ALL smoke management specifications met? & YES NO \\
\hline $\begin{array}{l}* \text { Are ALL planned operations personnel and equipment on-site, available and } \\
\text { operational? }\end{array}$ & YES NO \\
\hline $\begin{array}{l}\text { * Has the availability of contingency resources applicable to today's implementa- } \\
\text { tion been checked and are they available? }\end{array}$ & YES NO \\
\hline $\begin{array}{l}* \text { Have ALL personnel been briefed on the project objectives, their assign- } \\
\text { ment, safety hazards, escape routes, and safety zones? }\end{array}$ & YES NO \\
\hline
\end{tabular}

If all the questions were answered "YES" proceed with a test fire. Document the current conditions, location and results. If any questions were answered "NO", DO NOT proceed with the test fire: Implementation is not allowed.

After evaluating the test fire, in your judgment can the prescribed fire be carried out according to the prescribed fire plan and will it meet the planned objective? Circle: YES or NO

\footnotetext{
* Items required if checklist is modified *
} 


\section{Element 3: Complexity analysis summary}

This summary should include the same summary rationale that is in the complexity analysis in Appendix $\mathrm{C}$ of the prescribe fire plan.

\begin{tabular}{|c|c|c|c|}
\hline ELEMENT & RISK & \begin{tabular}{|l|} 
POTENTIAL \\
CONSEQUENCE
\end{tabular} & \begin{tabular}{|l|} 
TECHNICAL \\
DIFFICULTY
\end{tabular} \\
\hline 1. Potential for escape & & & \\
\hline $\begin{array}{l}\text { 2. The number and dep } \\
\text { activities }\end{array}$ & & & \\
\hline 3. Off-site values & & & \\
\hline 4. On-site values & & & \\
\hline 5. Fire behavior & & & \\
\hline 6. Management organiz & & & \\
\hline 7. Public and political i & & & \\
\hline 8. Fire treatment object & & & \\
\hline 9. Constraints & & & \\
\hline 10. Safety & & & \\
\hline 11. Ignition procedures/1 & & & \\
\hline 12. Interagency coordina & & & \\
\hline 13. Project logistics & & & \\
\hline 14. Smoke management & & & \\
\hline
\end{tabular}

\begin{tabular}{|l|l|}
\hline COMPLEXITY RATING SUMMARY & OVERALL RATING \\
\hline RISK & \\
\hline CONSEQUENCES & \\
\hline
\end{tabular}




\begin{tabular}{|c|c|}
\hline COMPLEXITY RATING SUMMARY & OVERALL RATING \\
\hline TECHNICAL DIFFICULTY & \\
\hline SUMMARY COMPLEXITY DETERMINATION & \\
\hline
\end{tabular}

Fill out Elements 4 through 21 based on the guidance provided in the Interagency Prescribed Fire Planning and Implementation Procedures Guide, PMS 484.

\section{Element 4: Description of prescribed fire area}

A. Physical Description

1. Location:

2. Size:

3. Topography:

4. Project area:

5. Ignition units:

B. Vegetation/Fuels Description:

1. On-site fuels data:

2. Adjacent fuels data:

3. Percent of vegetative type and fuels model(s):

C. Description of Unique Features, Natural Resources, Values:

D. Maps - Attach in Appendix A

1. Vicinity (Required)

2. Project/Ignition Unit(s) (Required)

3. Significant or Sensitive Features (Optional): $\square$ Included $\square$ Not Included

4. Fuels or Fuel Model(s)(Optional): $\square$ Included $\square$ Not Included

5. Smoke Impact Area (Optional): $\square$ Included $\square$ Not Included 


\section{Element 5: Objectives}
A. Resource objectives:
B. Prescribed fire objectives:

\section{Element 6: Funding}
A. Cost:
B. Funding source:

\section{Element 7: Prescription}

A. Prescription Narrative:

1. Describe how fire behavior will meet objectives

B. Prescription Parameters:

1. Environmental or fire behavior (or both)

2. Fire Modeling or empirical documentation (or both)

\section{Element 8: Scheduling}
A. Implementation Schedule:
1. Ignition Time Frames or Season(s) (or both)
B. Projected Duration:
C. Constraints:

\section{Element 9: Pre-burn considerations and weather}
A. Considerations:
1. On-site
2. Off-site
B. Method and Frequency for Obtaining Weather and Smoke Manage- ment Forecast(s):
C. Notifications: 


\section{Element 10: Briefing}

A. Briefing Checklist; including, but not limited to: (additional items may be added)

Burn organization and assignments

Prescribed Fire objectives and prescription

Description of prescribed fire project area

Special considerations and sensitive features

Expected weather and fire behavior

Communications

Ignition plan

Holding plan

Contingency plan and assignments

Wildfire declaration

Safety and medical plan

Aerial ignition briefing (if aerial ignition devices will be used)

\section{Element 11: Organization and equipment}
A. Positions:
B. Equipment:
C. Supplies:

\section{Element 12: Communication}

A. Radio Frequencies:

1. Command frequency(ies):

2. Tactical frequency(ies):

3. Air operations frequency(ies):

B. Telephone Numbers:

\section{Element 13: Public and personnel safety, medical}
A. Safety Hazards:
B. Mitigation: Measures Taken to Reduce the Hazards:
C. Emergency Medical Procedures:
D. Emergency Evacuation Methods:
E. Emergency Facilities: 


\section{Element 14: Test fire}

A. Planned Location:

B. Test Fire Documentation:

1. Weather conditions on site

2. Test fire results

\section{Element 15: Ignition plan}
A. Firing Methods:

1. Techniques, sequences and patterns

B. Devices:

C. Minimum Ignition Staffing:

\section{Element 16: Holding plan}
A. General Procedures for Holding:
B. Critical Holding Points and Actions:
C. Minimum Organization or Capabilities Needed:

\section{Element 17: Contingency plan}

Management Action Points or Limits:

(Optional MAP Table Format)

\begin{tabular}{|l|l|}
\hline $\begin{array}{l}\text { Management Action Point - } \\
\text { Documentation Element }\end{array}$ & Management Action Point Narrative \\
\hline Designator and Description: & \\
\hline Condition: & \\
\hline Management Intent: & \\
\hline $\begin{array}{l}\text { Recommended Action(s) to Consid- } \\
\text { er: }\end{array}$ & \\
\hline Recommended Resources: & \\
\hline Time Frame: & \\
\hline $\begin{array}{l}\text { Describe the consequences of not } \\
\text { taking the recommended action(s) } \\
\text { (Optional): }\end{array}$ & \\
\hline Responsibility: & \\
\hline
\end{tabular}




\begin{tabular}{|l|l|}
\hline $\begin{array}{l}\text { Management Action Point - } \\
\text { Documentation Element }\end{array}$ & Management Action Point Narrative \\
\hline $\begin{array}{l}\text { Date Each Action is Initiated (Op- } \\
\text { tional): }\end{array}$ & \\
\hline
\end{tabular}

(if you need to include more MAPs, copy and paste the above template)

B. Actions Needed:

C. Minimum Contingency Resources and Maximum Response Time(s):

\section{Element 18: Wildfire declaration}
A. Wildfire Declared By:
B. IC Assignment:
C. Notifications:
D. Extended Attack Actions and Opportunities to Aid in Fire Suppression (Optional):

\section{Element 19: Smoke management and air quality}
A. Compliance:
B. Permits to be Obtained:
C. Smoke-Sensitive Receptors:
D. Potential Impacted Areas:

E. Mitigation Strategies and Techniques to Reduce Smoke Impacts:

\section{Element 20: Monitoring}
A. Fuels Information Required and Procedures:
B. Weather Monitoring (Forecasted and Observed) Required and Proce- dures: 
C. Fire Behavior Monitoring Required and Procedures:

D. Monitoring Required to Ensure that Prescribed Fire Plan Objectives are Met:

E. Smoke Dispersal Monitoring Required and Procedures:

\section{Element 21: Post-burn activities}

A. Post-Burn Activities that must be Completed:

\section{Prescribed Fire Plan Appendices}

Appendix A: Maps: Vicinity, Project or Ignition Units (or both), Optional: Significant or Sensitive Features, Fuels or Fuel Model, Smoke Impact Areas

Appendix B: Technical Reviewer Checklist

Appendix C: Complexity Analysis

Appendix D: Agency-Specific Job Hazard Analysis or Risk Assessment

Appendix E: Fire Behavior Modeling Documentation or Empirical Documentation

Appendix F: Smoke Management Plan and Smoke Modeling Documentation (Optional)

\section{Appendix A: Vicinity Map}

Insert your vicinity maps here. Refer to Element 4D in the Interagency Prescribed Fire Planning and Implementation Procedures Guide, PMS 484, to fill out this appendix.

\section{Appendix A: Project (Ignition Units) Maps}

Insert your project (ignition unit) map(s) here. Refer to Element 4D in the Interagency Prescribed Fire Planning and Implementation Procedures Guide, PMS 484, to fill out this appendix.

\section{Appendix A: Significant or Sensitive Features: (Optional) Maps}

Insert your significant or sensitive feature map(s) here. Refer to Element 4D in the Interagency Prescribed Fire Planning and Implementation Procedures Guide, PMS 484, to fill out this appendix. 


\section{Appendix A: Fuels or Fuel Model: (Optional) Maps}

Insert your fuel or fuel model map(s) here. Refer to Element 4D in the Interagency Prescribed Fire Planning and Implementation Procedures Guide, PMS 484, to fill out this appendix.

\section{Appendix A: Smoke Impact Areas: (Optional) Maps}

Insert your significant or sensitive feature map(s) here. Refer to Element $4 \mathrm{D}$ in the Interagency Prescribed Fire Planning and Implementation Procedures Guide, PMS 484, to fill out this appendix.

\section{Appendix B: Technical Reviewer Checklist}

Fill out this checklist based on the guidance provided in the Technical Review section in the Interagency Prescribed Fire Planning and Implementation Procedures Guide, PMS 484.

Rate each element in the following table with an "S" for Satisfactory or "U" for Unsatisfactory. Use Comment field as needed to support the element rating.

\begin{tabular}{|l|l|l|}
\hline \multicolumn{1}{|c|}{ PRESCRIBED FIRE PLAN ELEMENTS } & RATING & COMMENTS \\
\hline 1. Signature page & & \\
\hline 2. A. Agency Administrator Ignition Authorization, PMS 485 & & \\
\hline 2. B. Prescribed Fire GO/NO-GO Checklist, PMS 486 & & \\
\hline 3. Complexity Analysis Summary & & \\
\hline 4. Description of Prescribed Fire Area & & \\
\hline 5. Objectives & & \\
\hline 6. Funding & & \\
\hline 7. Prescription: Prescription Narrative and Prescription Pa- & & \\
\hline 8. Scheduling & & \\
\hline 9. Pre-Burn Considerations and Weather & & \\
\hline 10. Briefing & & \\
\hline 11. Organization and Equipment & & \\
\hline 12. Communication & & \\
\hline 13. Public and Personnel Safety, Medical & & \\
\hline 14. Test Fire & & \\
\hline 15. Ignition Plan & & \\
\hline 16. Holding Plan & & \\
\hline 17. Contingency Plan & & \\
\hline 18. Wildfire Declaration & & \\
\hline 19. Smoke Management and Air Quality & & \\
\hline 2o. Monitoring & & \\
\hline 21. Post-Burn Activities & & \\
\hline Appendix A: Maps & & \\
\hline
\end{tabular}




\begin{tabular}{|l|l|l|}
\hline \multicolumn{1}{|c|}{ PRESCRIBED FIRE PLAN ELEMENTS } & RATING & COMMENTS \\
\hline Appendix C: Complexity Analysis & & \\
\hline $\begin{array}{l}\text { Appendix D: Agency-Specific Job Hazard Analysis or Risk As- } \\
\text { sessment }\end{array}$ & & \\
\hline $\begin{array}{l}\text { Appendix E: Fire Behavior Modeling Documentation or Empiri- } \\
\text { cal Documentation }\end{array}$ & & \\
\hline $\begin{array}{l}\text { Appendix F: Smoke Management Plan and Smoke Modeling } \\
\text { Documentation (Optional) }\end{array}$ & & \\
\hline Other & & \\
\hline
\end{tabular}

Approval is recommended subject to the completion of all requirements listed in the comments section, or on the Prescribed Fire Plan.

Recommendation for approval is not granted. Prescribed fire plan should be re-submitted for technical review subject to the completion of all requirements listed in the comments section, or on the Prescribed Fire Plan.

Technical Reviewer Signature:

Qualification and Currency:

Date Signed:

\section{Appendix C: Complexity Analysis}

Please refer to Element 3: Complexity Analysis Summary in the Interagency Prescribed Fire Planning and Implementation Procedures Guide, PMS 484, and the procedures in the Prescribed Fire Complexity Analysis Rating System Guide, PMS 424, to fill out this appendix.

\section{Appendix D: Agency-Specific Job Hazard Analysis or Risk Assessment}

Please refer to your specific agency guidance to fill out this appendix.

\section{Appendix E: Fire Behavior Modeling Documentation or Empirical Documentation}

Refer to Element 7: Prescription, in the Interagency Prescribed Fire Planning and Implementation Procedures Guide, PMS 484, to fill out this appendix. 


\section{Appendix F: Smoke Management Plan and Smoke Modeling Documentation}

\section{(OPTIONAL)}

Refer to the Smoke Management Guide for Prescribed and Wildland Fire (NWCG 2001) and Appendix B, "Basic Smoke Management Practices" in the Interagency Prescribed Fire Planning and Implementation Procedures Guide (NWCG 2014) to fill out this appendix. 


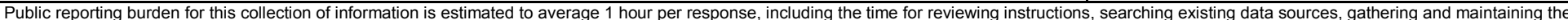

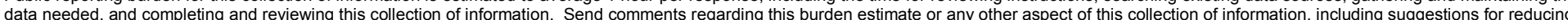

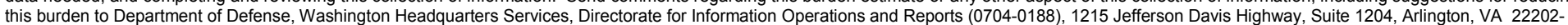

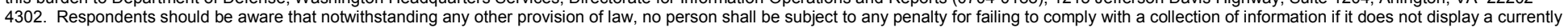
valid OMB control number. PLEASE DO NOT RETURN YOUR FORM TO THE ABOVE ADDRESS.
1. REPORT DATE (DD-MM-YYYY) 30-09-2015 2. REPORT TYPE Final

4. TITLE AND SUBTITLE

Developing Baselines for Prescribed Burning Smoke Management Plans and Best Management Practices

\section{AUTHOR(S)}

Michael R. Kemme

\section{DATES COVERED (From - To)}

5a. CONTRACT NUMBER

5b. GRANT NUMBER

5c. PROGRAM ELEMENT NUMBER

\section{5d. PROJECT NUMBER}

$652 \mathrm{BJ} 3$

5e. TASK NUMBER

\section{5f. WORK UNIT NUMBER}

8. PERFORMING ORGANIZATION REPORT NUMBER

ERDC/CERL TR-15-30

10. SPONSOR/MONITOR'S ACRONYM(S) OACSIM

11. SPONSOR/MONITOR'S REPORT NUMBER(S)

Army Environmental Division (ISE)

600 Army Pentagon

Washington, DC 20310-0600

\section{DISTRIBUTION / AVAILABILITY STATEMENT}

Approved for public release; distribution is unlimited.

\section{SUPPLEMENTARY NOTES}

\section{ABSTRACT}

Prescribed fire is a critical component of Army wildland fire management and prevention, range maintenance, and ecosystem management. The U.S. Environmental Protection Agency (EPA) sets policy on control-ling emissions from prescribed burning that is complex and still evolving. States have implemented EPA regulations and policy by developing their own regulations, Smoke Management Programs (SMPs), and State Implementation Plan conditions. A wide array of guidance for developing SMPs is available, along with tools for managing prescribed fire emissions. This information and many of these tools are applicable to Army installation management of prescribed burn smoke emissions. The Army already has the basic framework for developing SMPs within the installationlevel Integrated Wildland Fire Management Plan that requires information on smoke management. However, this work discusses and recommends an approach for developing complete Army SMPs that align with the required elements of state/tribal SMPs. It is also recommended that a great deal of flexibility should be allowed in the installation-level SMP to account for variation in an installation's need to control smoke emissions and to meet state regulatory requirements.

\section{SUBJECT TERMS}

Prescribed fire, smoke emissions, smoke management, wildland fire management, US Army ranges, smoke management plans

\begin{tabular}{|c|c|c|c|c|c|}
\hline \multicolumn{3}{|c|}{ 16. SECURITY CLASSIFICATION OF: } & 17. LIMITATION & 18. NUMBER & 19a. NAME OF RESPONSIBLE PERSON \\
\hline $\begin{array}{l}\text { a. REPORT } \\
\text { Unclassified }\end{array}$ & $\begin{array}{l}\text { b. ABSTRACT } \\
\text { Unclassified }\end{array}$ & $\begin{array}{l}\text { c. THIS PAGE } \\
\text { Unclassified }\end{array}$ & UU & 77 & $\begin{array}{l}\text { 19b. TELEPHONE NUMBER } \\
\text { (include area code) }\end{array}$ \\
\hline
\end{tabular}

